
\title{
$\begin{array}{ll}\text { Research Square } & \begin{array}{l}\text { Preprints are preliminary reports that have not undergone peer review. } \\ \text { They should not be considered conclusive, used to inform clinical practice, } \\ \text { or referenced by the media as validated information. }\end{array}\end{array}$
}

\section{Petrophysical Properties of Limestones - Influence On Behaviour Under Different Environmental Conditions And Applications}

\author{
Luís Sousa ( $\square$ lsousa@utad.pt ) \\ 9198-9365 \\ Johanna Menningen \\ University of Gottingen: Georg-August-Universitat Gottingen \\ Rubén López-Doncel \\ Autonomous University of San Luis Potosi: Universidad Autonoma de San Luis Potosi \\ Siegfried Siegesmund \\ University of Gottingen: Georg-August-Universitat Gottingen
}

University of Tras-os-Montes and Alto Douro: Universidade de Tras-os-Montes e Alto Douro https://orcid.org/0000-0002-

\section{Research Article}

Keywords: Limestones, textural characteristics, durability, weathering resistance, bowing

Posted Date: September 8th, 2021

DOI: https://doi.org/10.21203/rs.3.rs-862528/v1

License: (c) (i) This work is licensed under a Creative Commons Attribution 4.0 International License. Read Full License

Version of Record: A version of this preprint was published at Environmental Earth Sciences on November 29th, 2021. See the published version at https://doi.org/10.1007/s12665-021-10064-3. 


\section{Abstract}

Limestones have wide variety, namely by differences in the process of formation, mineralogical composition, grain size and texture. Such variability leads to differences in weathering characteristics and behaviour under different environmental conditions and applications. Therefore, detailed studies are mandatory to assess the main factors controlling the physicalmechanical properties and the durability to propose the best applications for the limestones. This study presents the petrographic and petrophysical data of eleven selected Portuguese limestones. Texture, mineralogy and porosity were identified as key parameters for the durability of limestones. Two main groups were identified regarding the texture/petrography and weathering resistance; the compact micritic limestones and with the sparitic grainstones. For the first time an outstanding bowing behaviour was identified in a limestone, probably related with clay swelling minerals and iron oxides present in the micrite groundmass around or in the stylolitic planes.

\section{Introduction}

Building stones have a high range of applications and worldwide production show an increasing tendency based in a continuous research in several related topics (Yarahmadi et al. 2018, 2019a; Montani 2017). In the past, aesthetical properties have been the first factor in building stone selection (Sousa et al. 2016; Santos et al. 2018) while the petrophysical properties have been of secondary importance. The knowledge about the interference of the stone properties in weathering and durability behaviour when employed in buildings was increased substantially in the last decades. There are many researches that point out the problems raised up by the misinformation about building stones and related conservation issues, especially in high porous materials (Unterwurzacher and Mirwald 2008; Siegesmund et al. 2010; Espinosa-Marzal et al. 2011; Stück et al. 2013; Wedekind et al. 2013; Molina et al. 2015; López-Doncel et al. 2016).

Limestones is probably the building stone type with a wider variety range, namely by differences in the process of formation, mineralogical composition, grain size and texture. Such variability of the carbonate rocks leads to differences in weathering characteristics and behaviour under different environmental conditions and applications (Freire-Lista et al. 2021). Textural and porous properties are the main factors ruling the stone behaviour, but weather conditions will enhance the degradation of the high porous materials. Barnoos et al. (2020) mention the presence of secondary calcite veins and clay veins in the microstructure of a limestone as cause for delamination and fragmentation and washing out during exposure to water, respectively. Yagiz (2011) identified random microcracks infilled with calcite, which turns the rock weaker than anticipated. The abrasion resistance is influenced by the internal structure of rock samples, being lower when cracks, gaps and large fossils are present (Özvan and Direk 2021). Nsari et al (2009) point out the importance of bioturbation, fissures, micro- and macroporosity in weathering characteristics and stone durability of limestone and carbonate tufa. Korkanç et al. (2021) studied a monument where a hard and low porous limestone does not appear to have sustained damage over thousands of years due to environmental conditions. With increasing acidity, the rate of weathering increases, and the mechanical properties decrease as pointed out by Fereidooni and Khajevand (2019) in accelerated weathering tests.

Physico-mechanical properties (PMP) reflect the variability of the limestones, especially the porosity and the compressive strength. Siegesmund and Dürrast (2014) in a statistical evaluation mention values of uniaxial compressive strength (UCS) in limestones ranging from 4.4 MPa to $265 \mathrm{MPa}$ and porosity values from $<1 \%$ to $>20 \%$. Arman et al. (2021) show data of rock strength of carbonate rocks with a wide range of variability and propose the derived correlation equations of the rock strength parameters. Despite the wide range of values for the physical-mechanical properties of limestones, some relationships are common. P-wave, UCS and density change jointly while the thermal conductivity has a negative correlation with porosity (Siegesmund and Dürrast 2014; Yaşar et al. 2008). These relationships help to select the best application (floor, façade, inside, outside, ...) for each material to maximize the properties in which the selection was made.

The knowledge of the PMP of stones used in heritage monuments is a critical issue, both to know the constraint factors dominating the evolution under specific environmental conditions and predict the durability and span of life of the buildings, and to choose the best solution when repairing works are necessary. The identification of the PMP of building stones can lead to their better maintenance and safekeeping (Taghipour et al. 2016; Korkanç et al. 2021), avoiding the use of inappropriate 
restoration material (Barnoos et al. 2020). When repairing or replacement of damaged stones is necessary, the best option is to use stones with similar properties from the original ancient quarries (Taghipour et al 2016). The conservation based on artificial products should always keep the resistance and appearance of the original material (Agan 2016).

The competitiveness in the building stone industry demands a clear picture of the possibilities of the different uses for each stone, point outing the qualities but also the limitations (Carvalho et al. 2013; Mustafa et al. 20126; Yarahmadi et al. 2019b). Different purposes as new construction or monument rehabilitation demand detailed information to ensure the best choice. A wrong application can have consequences for the image of a building stone that are hard to revert. Decades of marketing diplomacy can be destroyed by a single building where the stone was not judiciously selected. The above-mentioned factors, from texture to mechanical properties, should always be considered as critical information. In this line, in the present research eleven varieties of Portuguese limestones covering a wide range of textures and PMP was used. The main objective is to highlight the main factors controlling the physical-mechanical and durability behaviour and propose the best applications for limestones. The systematic evaluation of the factors controlling Portuguese limestone behaviour has never been done with such number of samples. Besides the insights about rock properties the results will be helpful to focus the communication target of limestone producers and traders.

\section{Materials And Methods}

The limestone samples used in this study were collected in the Maciço Calcário Estremho (MCE), a Jurassic limestone massif located in the Portuguese Lusitanian Basin, except for one sample (LIOZ) collected in a Cretaceous Unit near Lisbon (Silva, 2017) (Fig. 1).

MCE is one of the world's leading regions producers of limestone for ornamental purposes (Carvalho and Lisboa, 2018). The quarries develop along the hillside, with several benches, can reach depths around $50 \mathrm{~m}$ and are grouped exploitation sites (Fig. 1) (Carvalho and Lisboa, 2018). Several lithostratigraphic units are exploited and originate different ornamental varieties, from cream laminated calcarenites to grey calciclastic micritic limestones. The samples selected from MCE show this high variability. The following commercial varieties were selected: Alpinina (ALP), Ataíja Azul (ATAZ), Ataíja Creme (ATCR), Semi-rijo Codaçal (cut parallel to the sedimentary lamination, CODFV), Lioz (LIOZ), Moca 4M (cut perpendicular to the sedimentary lamination, MCCT), Semi-rijo Branco Mais(i) (SBM), Semi-rijo Branco Real (SBR), Vidraço Azul Valverde (VAV); Vidraço Portela Azul (VPAZ); Vidraço Portela Creme (VPCR). From here now the designations used are the ones indicated in brackets.

The limestones present different hues from beige to brown, according to the size of the bioclast and intraclast particles and cement constitution. Aleatory or laminated distribution of their constituents imprints a remarkable heterogeneity to some limestones. Most of the studied limestones show a light beige hue, and only ATAZ, VPAZ and VAV samples have dark hues (Fig. 2).

Thin sections were used to perform the petrographic studies. X-ray diffraction of whole-rock samples was used to determine the mineralogical and geochemical composition. The studied limestones were evaluated about the following properties: density, porosity, capillary water absorption, pore radii distribution, ultrasound velocity, thermal expansion, bowing potential, thermal shock, and salt burst tests. The general description of the methods is given below.

Open porosity and density were measured in $6.5 \mathrm{~cm}$ cubic samples using the hydrostatic weighting method (DIN 52102). The water-saturated mass and the buoyancy mass of the samples were measured after water saturation under vacuum, and the dry mass was used to calculate the porosity.

The capillary water absorption was measured on cubic samples with dimensions of $6.5 \mathrm{~cm}$ in length. The bottom plane of the cubes was placed into water (until a meniscus formed surrounding the entire sample) and the weight increase was measured.

The pore size distribution was measured by mercury intrusion porosimetry (MIP; Pascal 140 and Pascal 440 from Thermo Scientific) using irregular samples (ca. 1.0-1.5 g). Pressures up to $400 \mathrm{MPa}$ were used to evaluate the pore radii measured at around $0.005 \mu \mathrm{m}$.

Page $3 / 29$ 
Ultrasound measurements were performed using the compressional wave velocity. The Geotron Ultrasound generator USG 40 and the Oscilloscope Fluke Scope Meter 192 were used according to DIN EN 14579:2004. The examinations were carried out with a frequency of $350 \mathrm{kHz}$ on 3 cubes per sample for three orthogonal measurements and a mean of nine measurements on dry and wet samples.

Thermal expansion measurements were performed in the temperature range of $20^{\circ} \mathrm{C}$ to $90^{\circ} \mathrm{C}$ using a pushrod dilatometer (for details see Strohmeyer 2003; Koch and Siegesmund, 2004). The residual strain ( $\varepsilon R S)$ was determined during seven heatingcooling cycles: 3 dry cycles $20-90-20^{\circ} \mathrm{C}$; 4 wet cycles $20-90-20^{\circ} \mathrm{C}$. $\varepsilon$ RS is determined by the ratio between the sample length change after the heating-cooling cycles and the initial length (for details see Weiss et al. 2004; Zeisig et al. 2002; Shushakova et al. 2013).

To determine the bowing potential and its directional dependence, slabs of $40 \times 10 \times 3 \mathrm{~cm}$ were exposed to heating cycles (20$80-20^{\circ} \mathrm{C}$ per day), according to DIN EN 16306:2013-05, simulating in an extreme way the conditions at the building.

Additionally, specimens were exposed to thermo-hygric cycles, moisture on one side (samples lying on a mm-thick film of demineralised water) and cyclical heat from a heating pad $3 \mathrm{~cm}$ above the slab surface on the reverse side. One cycle included a heating period of $5 \mathrm{~h}$, where the surface finally reached $80^{\circ} \mathrm{C}$ and a cooling period of at least $12 \mathrm{~h}$, so that the duration of one cycle was 1 day. The bowing was measured using a measuring bridge with an accuracy of $1 \mu \mathrm{m} / 35 \mathrm{~cm}$ every first to the fourth cycle (see Koch and Siegesmund 2002, 2004; Grelk et al. 2004). A total of 105 cycles were performed.

Thermal shock test was performed in cubic samples with dimensions of $6.5 \mathrm{~cm}$ in length. After a period of about 16 hours in the oven at high temperatures $\left(100^{\circ} \mathrm{C}\right.$ and $\left.200^{\circ} \mathrm{C}\right)$, the samples were cooled in water at $10^{\circ} \mathrm{C}$ for 8 hours. A total of $34 \mathrm{cycles}$ were completed, 18 at $100^{\circ} \mathrm{C}$ and 16 at $200^{\circ} \mathrm{C}$. The samples were visually examined after each cycle and monitored with ultrasound measurements, performed after several cycles, before the samples dry completely at $60^{\circ} \mathrm{C}$. One cube per sample was used and the ultrasound value was taken from the mean value of three orthogonal measurements.

The salt crystallization test was performed according to the standard DIN EN 12370 . The samples ( $5 \mathrm{~cm}$ cubes) were soaked in a $10 \% \mathrm{Na}_{2} \mathrm{SO}_{4}$ solution. The samples were submerged for about four hours in the solution and then dried in an oven at $60^{\circ} \mathrm{C}$ for sixteen hours. After cooling to room temperature for four hours, the cubes were weighed to determine the loss of material.

\section{Results And Discussion}

\section{Petrography, mineralogy and geochemistry}

The thin section observations allow the identification of the main petrographic characteristics of the studied limestones, which are summarized below and illustrated in Fig. 3.

ALP - Tectonized micritic limestone with oncolits; show slight recrystallized and red stylolitic planes and calcite veins are remarkable features (Carvalho, 2013).

ATAZ - This variety is very compact and with a uniform texture. Is classified as a pelmicrite, with frequent bioclasts of small size (Carvalho, 2013).

ATCR - Similar to ATAZ with a cream hue. When impregnated by yellowish hydrated iron oxides the peloids can produce different hues (Carvalho et al. 2018).

CODFV - Bioclastic and oolithoclastic grainstone with abundant sparitic cement. A sedimentary lamination, visible by differences in grain size is a common feature (Fig. 3c). Large pores are frequent.

LIOZ - Microcrystalline, bioclastic, fossiliferous limestone. The fossil content of rudist is a remarkable feature of this stone (Silva, 2017). 
MCCT - This sample is made of coarse intraclasts and bioclasts and a variable amount of peloids, with abundant sparitic cement (Carvalho 2013; Carvalho et al. 2014). It shows evident lamination from alternating levels of different grain sizes and compositions (Fig. 3a). Large spheroidal or ellipsoidal pores are frequent.

SBR - Biolithoclastic limestone, with fine to coarse peloids and ooids. Large spheroidal or ellipsoidal pores are frequent.

SBM - Similar to SBR samples with a lighter hue. The outermost part of the peloids are slightly impregnated by yellowish hydrated iron oxides.

VPAZ - Micritic limestone with some marl content, occasionally oolitic, peloidal or intraclastic and bioclastic rich.

VPCR - Similar to VPAZ but with coarser bioclastic content. Consequently, as a lighter hue than VPAZ sample.

VAV - Micritic limestone with ooids, oncoids and bioclasts. Alternating levels with a variable proportion of allochemical components can be observed. Some iron-rich lines are observed in the packstone levels (see right side of Fig. $3 f$ ).

Table 1 the main characteristics of the selected limestones are presented, as well their classification according to Dunham (1962) and Folk (1962).

The pores are more frequent in the MCCT, CODFV, SBR and SBM samples, occurring dispersed in the thin sections. They are usually isolated spheroidal within the sparry cement and sometimes arranged as a circular crown around the allochemical components (Carvalho et al 2018). The mean pore size is comprised between $50 \mu \mathrm{m}$ and $200 \mu \mathrm{m}$ in limestones from MCE (Carvalho et al 2018), however some larger pores were observed and could be originated during the thin section preparation.

Table 1

General characteristics and classification of the selected limestones (according to Dunham (1962) and Folk (1962)).

\begin{tabular}{|c|c|c|}
\hline Sample & General characteristics & Classification \\
\hline ALP & $\begin{array}{l}\text { Grey limestone composed of a micritic matrix ( } 95 \%) \\
\text { and } 5 \% \text { of components }\end{array}$ & $\begin{array}{l}\text { Pelagic mudstone (after Dunham, 1962) and Micrite } \\
\text { (after Folk, 1962) }\end{array}$ \\
\hline ATAZ & $\begin{array}{l}\text { Light cream limestone with } 50 \% \text { groundmass and } \\
50 \% \text { components }\end{array}$ & $\begin{array}{l}\text { Peloidal wackestone (after Dunham, 1962) and } \\
\text { Pelmicrite (after Folk, 1962) }\end{array}$ \\
\hline ATCR & $\begin{array}{l}\text { Cream coloured limestone with } 60 \% \text { groundmass and } \\
40 \% \text { components }\end{array}$ & $\begin{array}{l}\text { Peloidal wackestone and packstone (after Dunham, } \\
\text { 1962) and Pelmicrite (after Folk, 1962) }\end{array}$ \\
\hline CODFV & $\begin{array}{l}\text { Light grey limestone composed of } 60 \% \text { sparry calcite } \\
\text { cement and } 40 \% \text { components }\end{array}$ & $\begin{array}{l}\text { Ooid-peloid grainstone (after Dunham, 1962) and } \\
\text { Oopelsparite (after Folk, 1962) }\end{array}$ \\
\hline LIOZ & $\begin{array}{l}\text { Fully recrystallized limestone composed of dolomite } \\
\text { microcrystals (dolosparite and dolomicrosparite) }\end{array}$ & Dolosparite (after Folk, 1962) \\
\hline МССТ & $\begin{array}{l}\text { Light cream limestones composed of } 50 \% \text { sparite } \\
\text { cement and } 50 \% \text { components }\end{array}$ & $\begin{array}{l}\text { Bioclastic grainstone (after Dunham, 1962) and } \\
\text { Biopelsparudite (after Folk, 1962) }\end{array}$ \\
\hline SBM & $\begin{array}{l}\text { Light cream limestone composed of } 40 \% \text { groundmass } \\
\text { and } 60 \% \text { components }\end{array}$ & $\begin{array}{l}\text { Peloidal grainstone (after Dunham, 1962) and } \\
\text { Pelsparite (after Folk, 1962) }\end{array}$ \\
\hline SBR & $\begin{array}{l}\text { Light cream limestone composed of } 40 \% \text { groundmass } \\
\text { and } 60 \% \text { components }\end{array}$ & $\begin{array}{l}\text { Ooid grainstone (after Dunham, 1962) and } \\
\text { Oosparudite (after Folk, 1962) }\end{array}$ \\
\hline VAV & $\begin{array}{l}\text { Light to medium grey limestone composed of } 70 \% \\
\text { groundmass and } 30 \% \text { components. }\end{array}$ & $\begin{array}{l}\text { Bioclastic packstone/grainstone (after Dunham, 1962) } \\
\text { and Biosparite/Biodismicrite (after Folk, 1962). }\end{array}$ \\
\hline VPAZ & $\begin{array}{l}\text { Medium grey limestone composed of a micritic matrix } \\
(>90 \%) \text { and less than } 10 \% \text { of components }\end{array}$ & $\begin{array}{l}\text { Pelagic Mudstone (after Dunham, 1962) and Micrite } \\
\text { (after Folk, 1962) }\end{array}$ \\
\hline VPCR & $\begin{array}{l}\text { Light grey limestone composed of } 60 \% \text { groundmass } \\
\text { and } 40 \% \text { components }\end{array}$ & $\begin{array}{l}\text { Bioclastic floatstone (after Dunham, 1962) and } \\
\text { Biomicrudite (after Folk, 1962). }\end{array}$ \\
\hline
\end{tabular}


These observations, namely the porosity, grain size, matrix and cement type (micrite/sparite) and allochems allow a first approach to the strength of the stones. Micrite and dolomite affect mechanical parameters positively while sparite and allochems decrease the strength parameters (Akram et al. 2017). Limestones with small crystals have a higher energy consumption during the wear than a macrocrystalline limestone, because the crack needs to pass more crystal boundaries which have a greater strength compared to cleavage planes (Jensen et al. 2010). Impurities as clay minerals decrease the strength and cause sudden changes in the microporous network characteristics and consequently turns variable the durability of the building stone (Tugrul and Zarif 2000; Jensen et al. 2010; Zammit and Cassar 2017).

The chemical composition of the studied limestones is very similar, with small differences (Table 2). The VAV limestone stands out showing a high quantity of magnesium and dolomite. In fact, VAV limestone shows a calcite percentage of 90.9 whilst the other limestones have values between $94.5 \%$ and $98.4 \%$. With magnesium carbonate the opposite happens: VAV - $4.8 \%$; others $-1.3 \%-2.6 \%$. These results are according to the information available in the Catalogue of Portuguese Ornamental Stones (Leite and Moura, 2021).

Table 2

Chemical composition of the limestones (values in percentage)

\begin{tabular}{|c|c|c|c|c|c|c|c|c|c|c|c|}
\hline & ALP & ATAZ & ATCR & CODFV & LIOZ & МсСТ & SBM & SBR & VAV & VPAZ & VPCR \\
\hline $\mathrm{CaO}$ & 55.47 & 54.53 & 54.42 & 55.33 & 55.22 & 55.43 & 55.34 & 55.42 & 52.39 & 53.79 & 54.34 \\
\hline MgO & 0.23 & 0.33 & 0.31 & 0.33 & 0.26 & 0.29 & 0.34 & 0.31 & 1.04 & 0.57 & 0.51 \\
\hline $\mathrm{SiO}_{2}$ & 0.13 & 0.59 & 0.84 & 0.1 & 0.34 & 0.05 & 0.09 & 0.05 & 1.46 & 1.06 & 0.71 \\
\hline $\mathrm{Fe}_{2} \mathrm{O}_{3}$ & 0.05 & 0.18 & 0.16 & 0.05 & 0.05 & 0.05 & 0.07 & 0.04 & 0.3 & 0.14 & 0.13 \\
\hline $\mathrm{Al}_{2} \mathrm{O}_{3}$ & 0.08 & 0.38 & 0.45 & 0.06 & 0.12 & 0.03 & 0.05 & 0.03 & 0.42 & 0.38 & 0.3 \\
\hline $\mathrm{K}_{2} \mathrm{O}$ & 0.02 & 0.03 & 0.03 & 0.01 & 0.01 & 0 & 0.01 & 0 & 0.08 & 0.03 & 0.03 \\
\hline $\mathrm{Mn}_{2} \mathrm{O}_{3}$ & 0.02 & 0.02 & 0.02 & 0.01 & 0.01 & 0.01 & 0.01 & 0.01 & 0.02 & 0.01 & 0.01 \\
\hline $\mathrm{Na}_{2} \mathrm{O}$ & 0.08 & 0.01 & 0.02 & 0.01 & 0 & 0 & 0.07 & 0 & 0.03 & 0.02 & 0.02 \\
\hline $\mathrm{SO}_{3}$ & 0.23 & 0.293 & 0.077 & 0.038 & 0.025 & 0.034 & 0.039 & 0.036 & 0.663 & 0.346 & 0.118 \\
\hline $\mathrm{CO}_{2}$ & 43.3 & 42.86 & 42.83 & 43.47 & 43.54 & 43.59 & 43.54 & 43.7 & 42.26 & 42.69 & 43.09 \\
\hline geb. $\mathrm{H}_{2} \mathrm{O}$ & 0.37 & 0.55 & 0.75 & 0.39 & 0.34 & 0.3 & 0.3 & 0.29 & 1.24 & 0.82 & 0.57 \\
\hline Total & 99.980 & 99.773 & 99.907 & 99.798 & 99.915 & 99.784 & 99.859 & 99.886 & 99.903 & 99.856 & 99.828 \\
\hline $\mathrm{CaCO}_{3}$ & 98.391 & 96.466 & 96.319 & 97.893 & 97.870 & 98.171 & 97.886 & 98.103 & 90.886 & 94.550 & 95.680 \\
\hline $\mathrm{MgCO}_{3}$ & 1.052 & 1.509 & 1.418 & 1.509 & 1.189 & 1.326 & 1.555 & 1.418 & 4.757 & 2.607 & 2.333 \\
\hline $\begin{array}{l}\mathrm{CaCO}_{3}+ \\
\mathrm{MgCO}_{3}\end{array}$ & 99.443 & 97.975 & 97.737 & 99.402 & 99.060 & 99.497 & 99.441 & 99.521 & 95.642 & 97.157 & 98.013 \\
\hline
\end{tabular}

\section{Density, porosity, pore radii}

The bulk density varies slightly between 2.61 and $2.71 \mathrm{~g} / \mathrm{cm}^{3}$ in eight samples and is lower $2.22-2.39 \mathrm{~g} / \mathrm{cm}^{3}$ in four samples because of the higher percentage of void space (Table 3), in accordance with published data (Matović and Ćalić 2016; Siegesmund and Dürrast 2014). Oolitic limestones show the lowest values as previously pointed out by Siegesmund and Dürrast (2014). The real or matrix density is close to the density of calcite, as is usual since it is the main component of the limestones studied (Matović and Ćalić 2016). 
Table 3

Obtained values of porosity, bulk density, matrix density and capillary water absorption (CWA).

\begin{tabular}{|lllll|}
\hline Stone & Bulk density $\left(\mathbf{g} / \mathrm{cm}^{3}\right)$ & Mtx density $(\mathrm{g} / \mathrm{cm} 3)$ & Porosity $(\%)$ & CWA $\left(\mathrm{Kg} / \mathrm{m}^{2} \mathbf{h}^{\mathbf{1} / 2}\right)$ \\
\hline ALP & 2.70 & 2.71 & 0.55 & 0.55 \\
\hline ATAZ & 2.69 & 2.70 & 0.47 & 0.37 \\
\hline ATCR & 2.67 & 2.70 & 1.17 & 0.86 \\
\hline CODFV & 2.28 & 2.71 & 16.11 & 2.94 \\
\hline LIOZ & 2.71 & 2.71 & 0.11 & 0.38 \\
\hline MCCT & 2.39 & 2.71 & 11.94 & 1.59 \\
\hline SBM & 2.22 & 2.71 & 18.80 & 5.50 \\
\hline SBR & 2.35 & 2.71 & 13.48 & 3.05 \\
\hline VAV & 2.64 & 2.71 & 1.27 & 0.81 \\
\hline VPAZ & 2.64 & 2.69 & 2.27 & 0.63 \\
\hline VPCR & 2.61 & 2.71 & 3.87 & 0.39 \\
\hline
\end{tabular}

The values of porosity show a wide range, from $0.11 \%$ in LIOZ limestone to $18.80 \%$ for the SBM variety, reflecting the span of rock types and related textures. These values of porosity are only valid for the studied samples and can be used as an approximated value for the limestone varieties since changes in the microporous network characteristics with depth of extraction have been reported (Tugrul and Zarif 2000; Zammit and Cassar 2017). Some varieties extracted in the MCE were previously studied and the porosity values range from 1.8-17.7\% (Alves et al. 2011; Carvalho et al. 2018). Even the companies mention high values of porosity for some of the varieties exploited in MCE (Solancis 2021).

Textural characteristics control the porosity, therefore micritic varieties have lower values than the detritical varieties, which display intergranular voids (Benavente et al. 2015; Ruffolo et al. 2017). Reflecting the textural properties in limestones, a wide range of values of porosity can be found in literature, from values lower than 2\% (Hashemi et al. 2018; Majeed et al. 2020; Hu et al. 2020; Korkanç et al. 2021) to values higher than 30\% (Turgut et al. 2008; Eslami et al. 2010; La Russa et al. 2013; Szemerey-Kiss and Török 2017; Van Stappen et al. 2019; Zenah et al. 2020). The high variability of the porosity of limestones aware about their durability, because the porosity is an excellent indicator of weathering (Tugrul and Zarif 2000) and strength properties (Nasri et al. 2019; Nabawy and El Aal 2019). As porosity is the key factor controlling most of the petrophysical properties and durability, the samples CODFV, MCCT, SBM and SBR probably will be the less resistant to weathering.

The pore radii distribution, porosity and water absorption are important parameters in stone conservation studies, being related to stone weathering resistance (Siegesmund and Dürrast 2014). Results from mercury intrusion show the pore access radii (Vásquez et al. 2013) meaning that not interconnected pores will not be recognized, while the cracks are accounted as pores. Furthermore, some disturbance occurs during the injection of the mercury and the porosity values will be higher than those obtained by hydrostatic weighting (Freire-Gormaly et al. 2015; Anovitz and Cole 2015; Sousa et al. 2017). From the several pore size classification schemes (Vásquez et al. 2013; Siegesmund and Dürrast 2014), the following was used: pores lower than 0.1 $\mu \mathrm{m}$ (micropores); pores higher than $0.1 \mu \mathrm{m}$ (capillary pores and macropores) (Klopfer 1985; Sousa et al. 2018). The pore sizes show an unequal bimodal distribution (see Ruedrich and Siegesmund 2006) with most of the pores distributed in the range between $0.01 \mu \mathrm{m}$ and $0.8 \mu \mathrm{m}$ and some pores with 10-50 $\mu \mathrm{m}$ (Fig. 4). Some samples exhibit a slightly tendency to a polymodal pore size distribution as pointed out by Nasri et al. (2019). According to Vásquez et al. (2013) the smallest pores (< $0.1 \mu \mathrm{m})$ are related with intragranular porosity, the largest pores $(>10 \mu \mathrm{m})$ represent the intergranular porosity and the intermedium size (around $1 \mu \mathrm{m}$ ) is the matrix porosity. The values of the pore access radii are low, with a mean value between $0.015 \mu \mathrm{m}$ to $0.298 \mu \mathrm{m}$ and mode values showing higher values, from $0.08 \mu \mathrm{m}$ to $0.53 \mu \mathrm{m}$ (Table 4). Clastic and most porous varieties (CODFV, MCCT, SBM and SBR) have the larger pore sizes, prevailing the matrix porosity with some intragranular pores. 
The same samples have a higher percentage of macroporosity (82.7\%-90\%), while the other samples show a higher microporosity (73.1\%-95.4\%). Besides a higher total porosity, the most porous samples have a higher potential of water absorption, with larger pores.

The values of pore access radii identified in previous researches show a wide range of values, according to the textural characteristics, pore network and methodology used in the determination. (Vásquez et al. 2013; Benavente et al. 2015; FreireGormaly et al. 2015; Török and Szemerey-Kiss 2019; Hu et al. 2020).

Table 4

Pore radii distribution, mean pore radii and percentage of micropores $(0.001 \mu \mathrm{m}$ to $0.1 \mu \mathrm{m} ; \%$ Micr) and macropores $(>0.1 \mu \mathrm{m}$;

\begin{tabular}{|c|c|c|c|c|c|c|c|c|c|}
\hline Stone & $\begin{array}{l}0.001-0.01 \\
\mu \mathrm{m}(\%)\end{array}$ & $\begin{array}{l}0.01-0.1 \\
\mu \mathrm{m}(\%)\end{array}$ & $\begin{array}{l}0.1-1 \mu \mathrm{m} \\
(\%)\end{array}$ & $\begin{array}{l}1-10 \mu \mathrm{m} \\
(\%)\end{array}$ & $\begin{array}{l}10-100 \mu \mathrm{m} \\
(\%)\end{array}$ & $\begin{array}{l}\text { Mean } \\
(\mu \mathrm{m})\end{array}$ & $\begin{array}{l}\text { Mode } \\
(\mu \mathrm{m})\end{array}$ & $\begin{array}{l}\% \\
\text { Micr }\end{array}$ & $\begin{array}{l}\% \\
\text { Macr }\end{array}$ \\
\hline ALP & 52.2 & 40.1 & 0.0 & 2.1 & 5.6 & 0.018 & 0.008 & 92.3 & 7.7 \\
\hline ATAZ & 48.2 & 34.4 & 4.4 & 0.0 & 15.9 & 0.033 & 0.008 & 79.7 & 20.3 \\
\hline ATCR & 48.2 & 47.1 & 0.0 & 0.0 & 4.7 & 0.016 & 0.008 & 95.3 & 4.7 \\
\hline CODFV & 1.5 & 10.1 & 83.1 & 2.8 & 2.5 & 0.299 & 0.53 & 11.6 & 88.4 \\
\hline LIOZ & 48.9 & 30.0 & 0.0 & 0.0 & 21.1 & 0.068 & 0.008 & 78.9 & 21.1 \\
\hline МССТ & 1.3 & 15.2 & 80.5 & 1.8 & 1.2 & 0.218 & 0.33 & 16.5 & 83.5 \\
\hline SBM & 3.1 & 6.9 & 83.2 & 2.6 & 3.4 & 0.298 & 0.33 & 10.0 & 90.0 \\
\hline SBR & 0.0 & 17.3 & 78.7 & 2.3 & 1.7 & 0.258 & 0.53 & 17.3 & 82.7 \\
\hline VAV & 25.5 & 61.1 & 5.1 & 2.2 & 6.1 & 0.030 & 0.013 & 86.6 & 13.4 \\
\hline VPAZ & 37.0 & 58.4 & 2.4 & 0.0 & 2.2 & 0.015 & 0.013 & 95.4 & 4.6 \\
\hline VPCR & 0.9 & 72.2 & 19.0 & 0.9 & 7.0 & 0.075 & 0.033 & 73.1 & 26.9 \\
\hline
\end{tabular}

\section{Water absorption and hydric expansion}

The dynamic of the absorption is similar for the stones (Fig. 5), but only the most porous (e.g., CODFV, MCCT, SBM and SBR) show a notorious water absorption. Within the first hours, the absorption of water is more evident and tends to stabilize after 6-9 hours, depending on the porous interconnectivity. After 24 hours the most porous samples show water uptake values in the range of $8.1-11.2 \mathrm{~kg} / \mathrm{m}^{2}$ and the others in the range of $0.2-0.6 \mathrm{~kg} / \mathrm{m}^{2}$. The sample SBM, with the highest porosity, reaches $100 \%$ of the weight absorption in 4 hours, revealing a good connection of the porous network. The water absorption is connected to the porosity and similar curves can be found in different types of rocks, but the size and connectivity of the pores affect the rate of absorption (Çelik and Kaçmaz 2016; Karagiannis et al. 2016; Feijoo et al. 2017; Sousa et al. 2018; Barroso et al. 2018). Sedimentary layering, stylolites, microfractures and heterogeneous micro-fabric impact the kinetic of water absorption in limestones (Tomašić et al. 2011; Siegesmund and Dürrast 2014; Zenah et al. 2020). As mentioned for porosity, CWA values show a wide range of values which are according to the published results (Siegesmund and Dürrast 2014; Vásquez et al. 2013, 2015; Benavente et al. 2015). Capillary water absorption (CWA) is higher in the porous samples (e.g., CODFV, MCCT, SBM and SBR) with values comprised between 1.59 and $5.50 \mathrm{~kg} / \mathrm{m}^{2} \mathrm{~h}^{1 / 2}$, and lower in the remaining samples, ranging from 0.37 to $0.86 \mathrm{~kg} / \mathrm{m}^{2} \mathrm{~h}^{1 / 2}$. These samples have a high percentage of macroporosity (> $\left.1 \mu \mathrm{m}\right)$ promoting the capillary imbibition and the water absorption rates (Benavente 2011; Benavente et al. 2015; Sousa et al. 2018; Nasri et al. 2019)

The values of hydric dilatation are lower than $0.09 \mathrm{~mm} / \mathrm{m}$, with exception of the Valverde (VAV) samples which reach $0.22-$ $0.26 \mathrm{~mm} / \mathrm{m}$ (Fig. 6). Usually, limestones show low hydric dilatation because these rocks have low clay content (Siegesmund and Dürrast, 2014). The presence of swelling clay is the cause for the dilation behaviour of natural stones and contributes to 
degradation (Wedekind et al. 2013; Cherblanc et al 2016; Nasri et al. 2019; Barnoos et al. 2020). Berthonneau et al. (2016) mention the effect of a low clay content $(<1.3 \%)$ in the macroscopic physical process of the hydric dilation. Aly et al. (2018) refer to the decaying forms related with the stylolitic planes, namely the unequal thermal expansion between the stone and the filling and/or the hydric expansion of the clay content of the stylolites. Gutiérrez et al. (2012) estimated a 12\% of clay content in samples of Azul Valverde limestone, a variety similar to the VAV sample. VAV sample has the high content of aluminium and silica (Table 2) which probably denotes some clay content. The dark material observed in microstylolites of the VAV sample can have some clay minerals and further investigations must be performed to investigate this issue.

\section{Ultrasonic wave velocity}

The values of the compressional waves (VP) range between $4049 \mathrm{~m} / \mathrm{s}$ to $5960 \mathrm{~m} / \mathrm{s}$, for the samples SBM and ATAZ, respectively (see Table 5). Porosity and textural characteristics have a great effect on the ultrasonic wave velocities and values from less than $2000 \mathrm{~m} / \mathrm{s}$ to more than $6500 \mathrm{~m} / \mathrm{s}$ can be found in literature, with significant variability among the specimens with high porosities (Kamh et al. 2017; Hashemi et al. 2018; Nina and Alber 2018; Freire-Lista et al. 2021). The VP depends on the density and elastic properties of the material (Rahman and Sarkar 2021). A good linear relationship between ultrasonic waves and open porosity in both dry and saturated conditions is found (Fig. 7), as observed in several investigations (Nina and Alber 2018; Nasri et al. 2019; Zenah et al. 2020). UCS values are usually related with VP (Çobanoğlu and Çelik 2008; Rahman and Sarkar 2021) which indicates that low porous samples (CODFV, MCCT, SBM and SBR) will have poor mechanical properties which is according to the results of similar varieties (the commercial designation is usually different from quarry to quarry) presented in the catalogues of Portuguese ornamental stones (Leite and Moura 2021; Assimagra 2021; Solancis 2021). In those catalogues the most varieties, similar to the porous limestones (CODFV, MCCT, SBM and SBR) show values of compression break load comprised between $50 \mathrm{MPa}$ and $70 \mathrm{MPa}$, whilst the other samples showed values between $105 \mathrm{MPa}$ and $150 \mathrm{MPa}$.

\section{Thermal dilatation}

Table 5

Compressional wave velocities on dry and wet samples

\begin{tabular}{|lll|}
\hline Stone & VP dry $(\mathrm{m} / \mathrm{s})$ & VP wet $(\mathrm{m} / \mathrm{s})$ \\
\hline ALP & 5692 & 6232 \\
\hline ATAZ & 5960 & 6052 \\
\hline ATCR & 5600 & 5819 \\
\hline CODFV & 4373 & 4452 \\
\hline LIOZ & 5728 & 6014 \\
\hline MCCT & 4536 & 4855 \\
\hline SBM & 4049 & 4110 \\
\hline SBR & 4321 & 4459 \\
\hline VAV & 5014 & 5270 \\
\hline VPAZ & 5555 & 5836 \\
\hline VPCR & 5408 & 5674 \\
\hline
\end{tabular}

The thermal dilatation coefficient a was calculated under dry and wet conditions. The mean values range from $3.80 \times 10^{-6} \mathrm{~K}^{-1}$ (VPCR) to $5.64 \times 10^{-6} \mathrm{~K}^{-1}$ (MCCT) and from $3.86 \times 10^{-6} \mathrm{~K}^{-1}$ (ALP) to $6.46 \times 10^{-6} \mathrm{~K}^{-1}$ (ATAZ), respectively in dry and wet states (Table 6). The mean values under dry and wet conditions are $4.63 \times 10^{-6} \mathrm{~K}^{-1}$ and $4.56 \times 10^{-6} \mathrm{~K}^{-1}$, respectively, being very similar. The overall mean value of the thermal dilatation coefficient from the twenty-two determinations is $4.60 \times 10^{-6} \mathrm{~K}^{-1}$. 
Systematic investigations of limestones are still missing but the results are according to the values previously obtained in this rock type and lower than those obtained in marbles (Siegesmund et al. 2010; Siegesmund and Dürrast 2014; Menningen et al. 2018).

The thermal dilatation $\varepsilon(\mathrm{mm} / \mathrm{m})$, as a function of temperature describes the expansion behaviour during thermal exposure and is plotted for all limestones in Figs. 8 and 9 under dry conditions. The slopes of the hysteresis curves are similar for all studied limestonesand almost linear.

The irreversible length change residual strain $(\varepsilon R S)$ under dry conditionsis almost zero, ranging from $-0.03 \mathrm{~mm} / \mathrm{m}$ in VAV sample to $0.11 \mathrm{~mm} / \mathrm{m}$ in MCCT sample. The negative values of residual strain near to zero are not meaningful, but the lowest value is found in the VAV sample, which probably has some clay content. Therefore, some dehydration reaction can occur as water is present in the pores. Under wet conditions, the residual strain is usually higher with values from $-0.01 \mathrm{~mm} / \mathrm{m}$ for the VPAZ sample up to $0.45 \mathrm{~mm} / \mathrm{m}$ for the CODFV sample. Five samples, which include the most porous ones (CODFV, LIOZ, MCCT, SBM and SBR), show a clear increase of the residual strain under wet conditions, with values in the range of $0.35-0.45$ $\mathrm{mm} / \mathrm{m}$. The remaining samples have a different behaviour: ALP, VPAZ and VPCR show low variations (from -0.01 to 0.8 $\mathrm{mm} / \mathrm{m}$ ); ATAZ, ATCR and VAV samples depict intermediate values (from 0.12 to $0.28 \mathrm{~mm} / \mathrm{m}$ ). As there are only few data of the residual strain in limestones available, a comparison is difficult. The results are higher than the value of $0.07 \mathrm{~mm} / \mathrm{m}$ found in Kuacker variety (Siegesmund et al. 2010) and lower than the results obtained for marbles (Siegesmund and Dürrast 2014; Menningen et al. 2018). 
Table 6

Thermal dilatation coefficient (a) and residual strain $\left(\varepsilon_{\mathrm{RS}}\right)$ after 3 dry and 4 wet cycles.

\begin{tabular}{|c|c|c|c|}
\hline Limestone & Condition & Average $\mathrm{a}\left(\times 10^{-6} \cdot \mathrm{K}^{-1}\right)$ & $\varepsilon_{\mathrm{RS}}(\mathrm{mm} / \mathrm{m})$ \\
\hline \multirow[t]{2}{*}{ ALP } & dry & 4.47 & -0.01 \\
\hline & wet & 3.86 & 0.02 \\
\hline \multirow[t]{2}{*}{ ATAZ } & dry & 4.86 & 0.01 \\
\hline & wet & 6.46 & 0.28 \\
\hline \multirow[t]{2}{*}{ ATCR } & dry & 4.32 & 0.00 \\
\hline & wet & 3.90 & 0.12 \\
\hline \multirow[t]{2}{*}{ CODFV } & dry & 4.85 & -0.01 \\
\hline & wet & 6.13 & 0.45 \\
\hline \multirow[t]{2}{*}{ LIOZ } & dry & 4.17 & 0.03 \\
\hline & wet & 4.35 & 0.35 \\
\hline \multirow[t]{2}{*}{ MCCT } & dry & 5.64 & 0.11 \\
\hline & wet & 4.13 & 0.39 \\
\hline \multirow[t]{2}{*}{ SBM } & dry & 5.07 & 0.04 \\
\hline & wet & 4.98 & 0.35 \\
\hline \multirow[t]{2}{*}{ SBR } & dry & 4.24 & 0.08 \\
\hline & wet & 4.20 & 0.35 \\
\hline \multirow[t]{2}{*}{ VAV } & dry & 4.82 & -0.03 \\
\hline & wet & 4.65 & 0.15 \\
\hline \multirow[t]{2}{*}{ VPAZ } & dry & 4.74 & -0.01 \\
\hline & wet & 3.65 & -0.01 \\
\hline \multirow[t]{2}{*}{ VPCR } & dry & 3.80 & 0.02 \\
\hline & wet & 3.90 & 0.08 \\
\hline
\end{tabular}

\section{Bowing test}

Previous results from a bowing test with 95 cycles show the absence of permanent changes in the selected limestones, with one exception (Sousa et al. 2020). During the first 24 cycles the bowing increases continuously and reaches the value of 7 $\mathrm{mm} / \mathrm{m}$, remaining stable in the next 41 dry cycles. The next stage of the wet cycles showed a new increase of the bowing with a maximum value around $9 \mathrm{~mm} / \mathrm{m}$ (Fig. 10a). Marble is the rock most prone to undergo such permanent deformation caused by the textural characteristics together with thermal strain in calcite (Siegesmund et al. 2000; Siegesmund et al. 2008; Menningen et al. 2018). Weathered granites can also display bowing behaviour (Sousa et al. 2017; Siegesmund et al. 2018). Although this phenomenon is described in many rock types there are scarce mentions to limestones (Siegesmund 2008).

To assess the bowing behaviour of the VAV sample, a new bowing test was performed in three specimens, with 105 cycles, mixing wet and dry cycles. The results confirm the bending of the VAV limestone, under the combined action of heat and water (Fig. 10b). The tested specimens display a similar evolution and the final bowing values range from $5.2 \mathrm{~mm} / \mathrm{m}$ to $6.8 \mathrm{~mm} / \mathrm{m}$. During the first 6 dry cycles the samples stay unchanged, then deformation increases until the 13th cycle under wet conditions 
and finally a small recovery occurs in next seven dry cycles. After two wet cycles (21-22) a combination of wet/dry cycles was performed until the 84th cycle. These combined wet/dry cycles show an overall tendency of bowing increase proportional to the number of wet cycles. In fact, between cycles 22 and 29 ( 2 wet/ 5 dry) and 66 and 70 ( 1 wet/3 dry) a small reduction in the bending is perceived, whilst the remain intervals of measurements, where the number of wet cycles is higher than the dry cycles, show a continuous increase of the deformation. With the exceptions of two dry cycles (92-93), the remaining cycles were performed under wet conditions and once again the velocity of bowing increases. The results reveal a clear influence of the water in the bowing evolution, being faster during successive wet cycles and slower when dry and wet cycles are interposed. It is also clear that the dry cycles only allow a small recovery of the bending.

The results are according to the behaviour of VAV limestone reported by several stoneworkers (Fig. 11). High values of bowing are frequently observed in marbles (Menningen et al. 2018) but are unknown in limestones. Furthermore, the mineralogy and texture of the selected limestones are very similar, which makes the bowing behaviour of the VAV sample strange. This samples has a residual strain value similar to the other studied limestones (see Table 6). The only different factor in the VAV sample are the microstylolites impregnated with iron oxides. The water plays an important role since no bending occurs when dry cycles are running. The hydric expansion only is observed in the VAV sample which is the variety with higher water loss and higher magnesium, silica, iron and aluminium content (see Table 2). Probably some clay and iron content associated with the stylolitic planes are the reasons for the unusual bowing displayed by the VAV limestone. Gutiérrez et al. (2012) noted the presence of montmorillonite, a swelling clay mineral, in a similar limestone variety. Further studies are necessary to assess if clay swelling minerals are present in the micrite groundmass around or in the stylolitic planes. As mentioned above a small clay content can have a deep impact on stone expansion (Berthonneau et al. 2016; Nasri et al. 2019; Barnoos et al. 2020).

\section{Thermal shock test}

The thermal shock test causes a small diminution of the VP values, which is more evident in the cycles at high temperatures $\left(200^{\circ} \mathrm{C}\right.$ ) especially in the most porous samples (Fig. 12). Fissures parallel to the cube faces and crossing all the samples are the only visible change, which probably is the cause for a fast decrease in the VP in some samples. Previous researches have shown that at temperatures up to $200^{\circ} \mathrm{C}$ an adjustment process occurs, and the small cracks gradually penetrate to form larger cracks (Meng et al. 2019). Existing microcracks and open porosity are key factors for the evolution of the limestones under increasing temperatures, as well as in freezing-thawing tests (Meng et al. 2020; Uğur and Toklu 2020). Grain size, texture, sedimentary layer can also affect the evolution of the limestones submitted to increased temperatures, however more evident effects are mentioned for higher temperatures (Pápay and Török 2018). Wang et al. (2020) refer an increase of about $0.2 \%$ and $0.7 \%$ when heated from 25 to $200^{\circ} \mathrm{C}$ and $200-300^{\circ} \mathrm{C}$, respectively, while Meng et al. (2019) mention more evident changes after $500^{\circ} \mathrm{C}$. Bisai et al. (2020) have shown that the combined process of heating followed by liquid nitrogen quenching causes more effect at $600^{\circ} \mathrm{C}$ with a reduction of about $62 \%$ in the UCS values. The results obtained in this experiment show that more massive and low porous limestones (ALP, ATAZ, ATCR, LIOZ, VAV, VPAZ, VPCR) seem to be more resistant to thermal shock, in accordance with previous properties.

\section{Salt crystallization test}

The results from the salt crystallization test depict a normal evolution of the samples weight (Fig. 13), with an increase in the first cycles following a progressive diminution according to the sample susceptibility (Nasri et al. 2018; Sousa et al. 2018). Visual inspection, used for monitoring the decay (Lubelli et al. 2018), denotes a progressive loss of material in some samples. The damage of a few millimetres can be very important when the stones are used for decorative purposes (Alves et al. 2011) where the primary consideration is the impact on aesthetic properties. After 16 cycles only the most porous samples (CODFV, MCCT, SBM and SBR) show signs of erosion (Fig. 13), starting at the corners and the edges, less notorious in the sample CODFV. The other samples only lose some material in previous cracks, stylolite joints, areas with heterogeneities as large elements or marked sedimentary layering (Fig. 14). However, the loss of material is balanced by the accumulation inside the porous network (Nasri et al. 2018) and only after around the 40th cycle weight diminution below the initial values is evident. The most porous samples have a maximum weight increase between $4 \%$ and $8 \%$, whilst the others increase below $1 \%$. The maximum loss is shown by the samples with high porosity as following, SBR lost $80 \%$ at cycle 54th, the SBM diminish $57 \%$ in 62 cycles, MCCT decreases $53 \%$ in 99 cycles and COFV depicts only $1.5 \%$ in 99 cycles. The sample LIOZ lose $0.5 \%$ related with

Page $12 / 29$ 
a detachment of small pieces while the remaining samples still have positive values at the end of the test (99 cycles), ranging from $0.1 \%$ for the ATAZ sample to $0.9 \%$ for the VPCR sample. The real weight loss is higher as the weight of salt crystallized inside the samples and can be higher than the weight decrease (see Vásquez et al. 2013).

A wide range of effects can be perceived from literature review, varying from high loss to small or any change (Alves et al. 2011; Vázquez et al. 2013; Ruffolo et al 2017) mainly as a consequence of porosity and pore network. The effect of salt is related to porosity, indicating that stones with the larger quantity of pores have more contact surfaces between crystals and pore walls. In these surfaces more crystallization pressure is exerted, and more damage occurs (Espinosa-Marzal and Scherer 2008). The sample SBR starts to lose weight earlier than sample SBM, despite their lower porosity (SBR-13.4\%; SBM-18.8\%). The high mode of pore radii in SBR sample (SBM-0.33 $\mu \mathrm{m}$; SBR- $0.53 \mu \mathrm{m})$ and the slightly impregnation by yellowish hydrated iron oxides of the peloids in the SBM sample can justify the fast deterioration of SBR. In this regard the result of CODFV is surprisingly better than expected considering their high porosity and pore radii distribution. Possible causes are the abundant sparitic cement, which prevents the detachment of grains and cementation of loose particles by salt (Lubelli et a. 2018). Sample preparation could infill the pores by smaller particles from the disaggregation of the limestone itself. Urosevic et al. (2013) point out differences in sea spray ageing test as a consequence of the reduction of the interconnectivity and open porosity due to polishing. Such causes are not reasonable to justify the results of CODFV and more studies are necessary to understand the behaviour of this stone under salt-action.

The stones can be ranked according to their response to the salt crystallization to the test (Lubelli et al. 2014). However, not only the weight variation should be considered in this evaluation to consider cases like the CODFV sample (see Lubelli et al. 2018). Furthermore, when stones are used for their aesthetic appealing even small damages need to be considered. So, considering the results of the salt test the most porous stones (CODFV, MCCT, SBM and SBR) should be considered as susceptible to salt-action, whilst the other samples are resistant.

\section{Summary And Conclusions}

Eleven commercial varieties of Portuguese limestones were studied to assess the influence of the textural characteristics in the physical-mechanical properties and durability behaviour. Some important conclusions can be draw:

- The selected varieties have a wide range of petrographic features, according to the grain size, matrix and cement type (micrite/sparite) and abundance of allochems. Two main groups were identified regarding the texture/petrography, one with the compact micritic limestones classified as pelagic mudstones or peloidal wackestones, the other with grainstones sparitic varieties as the peloidal, bioclastic and ooid grainstones. The chemical composition of the studied limestones is very similar, however the Vidraço Azul Valverde (VAV) limestone stands out showing a high quantity of magnesium. In fact, VAV limestone shows $90.9 \%$ of calcite whilst the other limestones have values between $94.5 \%$ and $98.4 \%$. With magnesium carbonate the opposite happens, the VAV limestone show a value of $4.8 \%$, the other limestones have values in the range $1.3 \%-2.6 \%$.

- The matrix density is close to the density of calcite, since it is the main component of the limestones studied. The bulk density varies slightly between 2.61 and $2.71 \mathrm{~g} / \mathrm{cm}^{3}$ in eight samples and is lower with $2.22-2.39 \mathrm{~g} / \mathrm{cm}^{3}$ in four grainstones varieties because of the higher percentage of void space.

- The values of porosity show a wide range, from $0.11-18.80 \%$, reflecting the span of rock types and related textures. Since the porosity is an excellent indicator of weathering, the high values can be used as analert for the potentially low durability of the most porous varieties in some applications/environmental conditions. The interconnected porosity shows an unequal bimodal distribution with most of the pores distributed in the range between $0.01 \mu \mathrm{m}$ and $0.8 \mu \mathrm{m}$ and some pores with 10-50 $\mu \mathrm{m}$. The clastic and most porous varieties (CODFV, MCCT, SBM and SBR) have larger pore sizes and a higher percentage of macroporosity $(>0.1 \mu \mathrm{m})$. Besides a higher total porosity, the most porous samples have a higher potential of water absorption which has been confirmed by the results of the capillary water absorption. In fact, the most porous samples show values of capillary water absorption comprised between 1.59 and $5.50 \mathrm{~kg} / \mathrm{m}^{2} \mathrm{~h}^{1 / 2}$, whilst the remaining samples have values in the range $0.37-0.86 \mathrm{~kg} / \mathrm{m}^{2} \mathrm{~h}^{1 / 2}$.

Page $13 / 29$ 
- The values of hydric dilatation are lower than $0.09 \mathrm{~mm} / \mathrm{m}$, with exception of the Valverde (VAV) samples which reach $0.22-0.26 \mathrm{~mm} / \mathrm{m}$ (Fig. 6). The hydric expansion of the VAV sample together with their high content of aluminium and silica (when compared with other studied limestones) presume that some clay content is present.

- The compressional wave velocities range between $4049 \mathrm{~m} / \mathrm{s}$ to $5960 \mathrm{~m} / \mathrm{s}$, having a good linear relationship to the open porosity and the available data of uniaxial compressive strength. Therefore, the compressional wave velocity is a good and non-destructive index to assess the suitability of limestone as building material.

- The values of the thermal dilatation coefficientundern dry and wet conditions are very similar, with mean values of the eleven samples of $4.63 \times 10^{-6} \mathrm{~K}^{-1}$ and $4.56 \times 10^{-6} \mathrm{~K}^{-1}$, respectively. Under dry conditions the residual strain is almost zero and increases under wet conditions especially in the most porous varieties reaching the highest value $(0.45 \mathrm{~mm} / \mathrm{m})$ in CODFV sample.

- The results of the bowing test confirm the bending of the VAV limestone, under the combined action of heat and water, with final bowing values in the range $5.2-6.8 \mathrm{~mm} / \mathrm{m}$. The results reveal a clear influence of the water in the bowing evolution, being faster during successive wet cycles and slower when dry and wet cycles are intercalated. The residual strain of the VAV sample is like the other studied limestones. Probably some clay and iron content associated with the stylolitic planes are the reason for the unusual bowing displayed.

- The thermal shock test causes a small diminution of the VP values, which is more evident in the cycles at high temperatures $\left(200^{\circ} \mathrm{C}\right)$ especially in the most porous samples. For the normal applications the limestones will not be affected by the action of the temperature.

- The results from the salt crystallization test depict a normal evolution of the samples weight, with an increase in the first cycles following a progressive diminution according to the sample susceptibility. The most porous stones (CODFV, MCCT, SBM and SBR) should be considered as susceptible to salt-action, whilst the other samples are resistant.

From the main conclusions enumerated above, the importance of the texture and the petrographic features are notorious in the porosity of limestones. The compact micritic samples have lower porosities than the grainstones sparitic varieties. Porosity is the key factor in the limestone behaviour, affecting the water absorption and durability under salt action.

Notwithstanding the high values of porosity, the limestones can be used as long as they meet the standards for the several applications and resist to the environmental conditions of their application. This already has been done by the extracting and processing companies. This is a decisive factor as a wrong application can have serious consequences and decades of marketing diplomacy can be lost by a single building where the stone was not judiciously selected.

Evidences of bowing in limestones are scarce and have low values, but the bending shown by the VAV samples is outstanding. Further studies are necessary to assess if clay swelling minerals and iron oxides are present in the micrite groundmass around or in the stylolitic planes which are typical in the studied samples. Additionally, the study of the sedimentary layering and their variation in the outcrops/quarries is important to define the areas of rock mass more prone to bowing. Meanwhile it is suggested that this variety should not be used in external applications under wet conditions and effect of temperature.

\section{Declarations}

\section{Acknowledgements}

This study was supported by the Fundação para a Ciência e a Tecnologia in the frame of the UIDB/00073/2020 and UIDP/00073/2020 projects of the I\&D unit Geosciences Center (CGEO). Authors are grateful to Solancis for supply the samples used in this research.

\section{References}

1. Agan C (2016) A preliminary study on the conservation and polishing performance of Sanliurfa limestones as a traditional building material. Bull Eng Geol Environ 75:13-25. https://doi.org/10.1007/s10064-015-0729-6

Page $14 / 29$ 
2. Akram MS, Farooq S, Naeem M, Ghazi S (2017) Prediction of mechanical behaviour from mineralogical composition of Sakesar limestone, Central Salt Range, Pakistan. Bull Eng Geol Environ 76:601-615. https://doi.org/10.1007/s10064-016$1002-3$

3. Alves C, Figueiredo C, Maurício A, Braga MAS, Aires-Barros L (2011) Limestones under salt decay tests: assessment of pore network-dependent durability predictors. Environ Earth Sci 63:1511-1527. https://doi.org/10.1007/s12665-011-09151

4. Aly N, Wangler T, Török Á (2018) The effect of stylolites on the deterioration of limestone: possible mechanisms of damage evolution. Environ Earth Sci 77:565. https://doi.org/10.1007/s12665-018-7746-2

5. Anovitz LM, Cole DR (2015) Characterization and analysis of porosity and pore structures. Rev Mineral Geochem 80:61164. https://doi.org/10.2138/rmg.2015.80.04

6. Arman H, Abdelghany O, Saima MA et al (2021) Petrological control on engineering properties of carbonate rocks in arid regions. Bull Eng Geol Environ. https://doi.org/10.1007/s10064-021-02211-8

7. Assimagra (2021) Portuguese Stone Catalogue. https://www.assimagra.pt/3d-flip-book/catalogo-da-pedra-portuguesa/. Accessed in 7th July 2021

8. Barnoos V, Oudbashi O, Shekofteh A (2020) The deterioration process of limestone in the Anahita Temple of Kangavar (West Iran). Heritage Science 8:66. https://doi.org/10.1186/s40494-020-00411-1

9. Barroso CE, Oliveira DV, Ramos LF (2018) Vernacular schist farm walls: materials, construction techniques and sustainable rebuilding solutions. J Build Eng 15:334-352. https://doi.org/10.1016/j.jobe.2017.12.001

10. Benavente $D$ (2011) Why pore size is important in the deterioration of porous stones used in the built heritage. Macla 15:41-42

11. Benavente D, Pla C, Cueto N, Galvañ S, Martínez-Martínez J, García-del-Cura MA, Ordóñez S (2015) Predicting water permeability in sedimentary rocks from capillary imbibition and pore structure. Eng Geol 195:301-311

12. Berthonneau J, Bromblet P, Cherblanc F, Ferrage E, Vallet J-M, Grauby $O$ (2016) The spalling decay of building bioclastic limestones of Provence (South East of France): From clay minerals swelling to hydric dilation. Journal of Cultural Heritage 17:53-60. DOI:10.1016/j.culher.2015.05.004

13. Berthonneau J, Grauby O, Ferrage E, Vallet JM, Bromblet P, Dessandier D, Chaudanson D, Baronnet A (2014) Impact of swelling clays on the spalling decay of building limestones: insights from X-ray diffraction profile modeling. Eur J Miner 26:643-656. DOI:10.1127/0935-1221/2014/0026-2393

14. Bisai R, Palaniappan SK, Pal SK (2020) Effects of high-temperature heating and cryogenic quenching on the physicomechanical properties of limestone. SN Appl Sci 2:158. https://doi.org/10.1007/s42452-020-1944-8

15. Carvalho C, Silva Z, Simão J (2018) Evaluation of Portuguese limestones' susceptibility to salt mist through laboratory testing. Environ Earth Sci 77:523. https://doi.org/10.1007/s12665-018-7670-5

16. Carvalho JMF (2013) Tectónica e caraterização da fraturação do Maciço Calcário Estremenho, Bacia Lusitaniana. Contributo para a prospeção de rochas ornamentais e ordenamento da atividade extrativa. Ph.D. Thesis, Universidade de Lisboa (in Portuguese)

17. Carvalho JMF, Lisboa JV, Moura AC, Carvalho C, Sousa LMO, Leite MM (2013) Evaluation of the Portuguese ornamental stone resources. Key Eng Mater 548:3-9. doi:10.4028/www.scientific.net/KEM.548.3

18. Carvalho JMF, Sampaio J, Machado S, Midões C, Prazeres C, Sardinha R (2014) Caracterização e valorização da área de intervenção específica de Pé de Pedreira. Cluster da Pedra Natural. 237 pp

19. Çelik MY, Kaçmaz AU (2016) The investigation of static and dynamic capillary by water absorption in porous building stones under normal and salty water conditions. Environ Earth Sci 75:307. https://doi.org/10.1007/s1266 5-015-5132-x

20. Cherblanc F, Berthonneau J, Bromblet P, Huon V (2016) Influence of water content on the mechanical behaviour of limestone: role of the clay minerals content. Rock Mech Rock Eng 49:2033-2042. DOI 10.1007/s00603-015-0911-y

21. Çobanoğlu İ, Çelik SB (2008) Estimation of uniaxial compressive strength from point load strength, Schmidt hardness and P-wave velocity. Bull Eng Geol Environ 67:491-498. https://doi.org/10.1007/s10064-008-0158-x

Page $15 / 29$ 
22. DIN EN 14579:2004, Prüfverfahren für Naturstein - Bestimmung der Geschwindigkeit der Schallausbreitung; Deutsche Fassung EN 14579:2004

23. DIN EN 16306:2013-05, Prüfverfahren für Naturstein_- Bestimmung der Beständigkeit von Marmor bei zyklischer Belastung mit Wärme und Feuchtigkeit; Deutsche Fas-sung EN_16306:2013. Beuth Verlag GmbH, Berlin. doi:10.31030/1910871

24. Dunham RJ (1962) Classification of carbonate rocks according to depositional textures. In Ham, W.E. (ed.), Classification of Carbonate Rocks: American Association of Petroleum Geologists, Memoir 1, 108-121

25. Eslami J, Grgic D, Hoxha D (2010) Estimation of the damage of a porous limestone from continuous (P-and S-) wave velocity measurements under uniaxial loading and different hydrous conditions. Geophys J Int 183:1362-1375. doi:10.1111/j.1365-246X.2010.04801.x

26. Espinosa-Marzal RM, Hamilton A, McNall M, Whitaker K, Scherer GW (2011) The chemomechanics of crystallization during rewetting of limestone impregnated with sodium sulfate. J Mater Res 26(12):1472-1481. https://doi.org/10.1557/jmr.2011.137

27. Espinosa-Marzal RM, Scherer GW (2008) Crystallization of sodium sulfate salts in limestone. Environ Geol 56:605-621. https://doi.org/10.1007/s0025 4-008-1441-7

28. Feijoo J, Nóvoa XR, Rivas T (2017) Electrokinetic treatment to increase bearing capacity and durability of a granite. Mater Struct 50:251. https://doi.org/10.1617/s1152 7-017-1123-6

29. Fereidooni D, Khajevand R (2019) Utilization of the accelerated weathering test method for evaluating the durability of sedimentary rocks. Bull Eng Geol Environ 78, 2697-2716 (2019). https://doi.org/10.1007/s10064-018-1267-9

30. Folk RL (1962) Spectral subdivision of limestones types. In Ham, W.E. (ed.), Classification of Carbonate Rocks: American Association of Petroleum Geologists, Memoir 1, 62-84

31. Freire-Gormaly M, Ellis JS, MacLean HL, Bazylak A (2015) Pore structure characterization of Indiana Limestone and Pink Dolomite from pore network reconstructions. Oil \& Gas Science and Technology-Rev. IFP Energies Nouvelles. DOI: $10.2516 /$ ogst/2015004

32. Freire-Lista DM, Sousa L, Carter R, Al-Naîmī F (2021) Petrography and petrophysical characterisation of the heritage stones of Fuwairit Archaeological Site (NW Qatar) and their historical quarries: implications for heritage conservation. Episodes 44(1):43-58. https://doi.org/10.18814/epiiugs/2020/0200s12

33. Grelk B, Goltermann P, Schouenborg B, Koch A, Alnaes L (2004) The laboratory testing of potential bowing and expansion of marble. In: Proceedings of the international conference on dimension stone 2004, 14-17 June 2004, Prague, pp 253259

34. Gutiérrez J, Mas A, Gil E, Galvañ V (2012) Clay-related damage in rainscreen walls built with natural stone coverings. Constr Build Mater 29:357-367. doi:10.1016/j.conbuildmat.2011.10.060

35. Hashemi M, Bashiri Goudarzi M, Jamshidi A (2018) Experimental investigation on the performance of Schmidt hammer test in durability assessment of carbonate building stones against freeze-thaw weathering. Environ Earth Sci 77:684. https://doi.org/10.1007/s12665-018-7874-8

36. Hu Z, Klaver J, Schmatz J, Dewanckele J, Littke R, Krooss BM, Amann-Hildenbrand A (2020) Stress sensitivity of porosity and permeability of Cobourg limestone. Eng Geol 273. https://doi.org/10.1016/j.enggeo.2020.105632

37. Jensen LRD, Friis H, Fundal E, Møller P, Jespersen M (2010) Analysis of limestone micromechanical properties by optical microscopy. Eng Geol 110:43-50. doi:10.1016/j.enggeo.2009.10.004

38. Kamh GME, Koltuk S, Ismael H (2017) Refinement of categorization and scaling of weathering-related damage to natural stone: case study on oolitic limestone from El-Shatbi Tombs (Egypt). Bull Eng Geol Environ 76, 39-57 (2017). https://doi.org/10.1007/s10064-016-0946-7

39. Karagiannis N, Karoglou M, Bakolas A, Moropoulou A (2016) Building materials capillary rise coefficient: concepts, determination and parameters involved. In: Delgado $\mathrm{J}(\mathrm{ed})$ New approaches to building pathology and durability. Building pathology and rehabilitation, vol 6. Springer, Singapore

40. Klopfer H (1985) Feuchte. In: Lutz et al (eds) Lehrbuch der Bauphysik. Teubner, Stuttgart

Page 16/29 
41. Koch A, Siegesmund S (2002) Bowing of marble panels: on-site damage analysis from the Oeconomicum building at Goettingen (Germany). Geological Society, London, Special Publications 205(1):299-314

42. Koch A, Siegesmund S (2004) The combined effect of moisture and temperature on the anomalous expansion behaviour of marble. Environ Geol 46:350-363

43. Korkanç M, İnce İ, Hatır ME, Tosunlar MB (2021) Atmospheric and anthropogenic deterioration of the İvriz rock monument: Ereğli-Konya, Central Anatolia, Turkey. Bull Eng Geol Environ 80:3053-3063. https://doi.org/10.1007/s10064-021-02105-9

44. La Russa MF, Ruffolo SA, Belfiore CM, Aloise P, Randazzo L, Rovella N, Pezzino A, Montana G (2013) Study of the effects of salt crystallization on degradation of limestone rocks. Periodico Mineral 82(1):113-127.

https://doi.org/10.2451/2013PM0007

45. Leite MRM, Moura AC (2021) Catalogue of Portuguese Ornamental Stones. INETI. Published online in https://rop.Ineg.pt/rop/images/intro/intr_en.php. Accessed in 23th Jun 2021

46. López-Doncel RA, Wedekind W, Cardona-Velázquez N, González-Sámano PS, Dohrmann R, Siegesmund S, Pötzl C (2016) Geological studies on volcanic tuffs used as natural building stones in the Historical Center of San Luis Potosí, Mexico. In: Hughes JJ, Howind T (eds) Science and art: a future for stone. Proceedings of the 13th international congress on the deterioration and conservation of stone, pp 107-105. University of the West of Scotland, Paisley

47. Lubelli B, Cnudde V, Diaz-Goncalves T et al (2018) Towards a more effective and reliable salt crystallization test for porous building materials: state of the art. Mater Struct 51:55

48. Lubelli B, van Hees RPJ, Nijland TG (2014) Salt crystallization damage: how realistic are existing ageing tests? AMS '14 Proceedings of the International Conference on Ageing of Materials \& Structures, Delft, The Netherlands, pp 103-111

49. Majeed Y, Abu Bakar MZ, Butt IA (2020) Abrasivity evaluation for wear prediction of button drill bits using geotechnical rock properties. Bull Eng Geol Environ 79:767-787. https://doi.org/10.1007/s10064-019-01587-y

50. Matović V, Ćalić TV (2016) Mesozoic carbonate rocks in Serbia used as dimension stone. Bull Eng Geol Environ 75:1-12. https://doi.org/10.1007/s10064-015-0722-0

51. Meng Q, Zhang M, Han L, Chen Y (2019) Experimental research on the influence of loading rate on the mechanical properties of limestone in a high-temperature state. Bull Eng Geol Environ 78:3479-3492. https://doi.org/10.1007/s10064018-1332-4

52. Meng QB, Wang CK, Liu JF et al (2020) Physical and micro-structural characteristics of limestone after high temperature exposure. Bull Eng Geol Environ 79:1259-1274. https://doi.org/10.1007/s10064-019-01620-0

53. Menningen J, Siegesmund S, Lopes L, Martins R, Sousa L (2018) The Estremoz marbles: an updated summary on the geological, mineralogical and rock physical characteristics. Environ Earth Sci 77:191. https://doi.org/10.1007/s12665-0187328-3

54. Molina E, Benavente D, Sebastian E, Cultrone G (2015) The influence of rock fabric in the durability of two sandstones used in the Andalusian Architectural Heritage (Montoro and Ronda, Spain). Eng Geol 197:67-81.

https://doi.org/10.1016/j.enggeo.2015.08.009

55. Montani C (2017) XXVIII report marble and stones in the world 2016. Ed. Aldus, Carrara

56. Mustafa S, Khan MA, Khan MR, Sousa LMO, Hameed F, Mughal MS, Niaz A (2016) Building stone evaluation-A case study of the sub-Himalayas, Muzaffarabad region, Azad Kashmir, Pakistan. Eng Geol 209:56-69. DOI 10.1016/j.enggeo.2016.05.007

57. Nabawy BS, El Aal AA (2019) Impacts of the petrophysical and diagenetic aspects on the geomechanical properties of the dolomitic sequence of Gebel El-Halal, Sinai, Egypt. Bull Eng Geol Environ 78:2627-2640. https://doi.org/10.1007/s10064018-1264-z

58. Nasri F, Boumezbeur A, Benavente D (2019) Influence of the petrophysical and durability properties of carbonate rocks on the deterioration of historic constructions in Tebessa (northeastern Algeria). Bull Eng Geol Environ 78:3969-3981. https://doi.org/10.1007/s10064-018-1410-7 
59. Nina H, Alber M (2018) Variation of laboratory test results with specimen size in carbonates of Bavarian Malm. Paper presented at the ISRM European Rock Mechanics Symposium - EUROCK 2018, St. Petersburg, Russia, May 2018

60. Özvan A, Direk N (2021) The relationships among different abrasion tests on deteriorated and undeteriorated rocks. Bull Eng Geol Environ 80:1745-1756. https://doi.org/10.1007/s10064-020-02041-0

61. Pápay Z, Török Á (2018) Effect of thermal and freeze-thaw stress on the mechanical properties of porous limestone. Periodica Polytechnica Civil Engineering, 62:423-428, 2018. https://doi.org/10.3311/PPci.11100

62. Rahman T, Sarkar K (2021) Lithological control on the estimation of uniaxial compressive strength by the P-wave velocity using supervised and unsupervised learning. Rock Mech Rock Eng. https://doi.org/10.1007/s00603-021-02445-8

63. Randazzo L et al (2021) Pore Structure and Water Transfer in Pietra d'Aspra Limestone: A Neutronographic Study. Appl. Sci. 2020, 10, 6745; doi:10.3390/app10196745

64. Ruedrich J, Siegesmund S (2007) Salt and ice crystallisation in porous sandstones. Environ Geol 52(2):225-249

65. Ruffolo SA, La Russa MF, Ricca M et al (2017) New insights on the consolidation of salt weathered limestone: the case study of Modica stone. Bull Eng Geol Environ 76, 11-20 (2017). https://doi.org/10.1007/s10064-015-0782-1

66. Santos I, Sousa L, Lourenço J (2018) Granite resources evaluation - example of an extraction area in North of Portugal. Environ Earth Sci 77:608. https://doi.org/10.1007/s12665-018-7780-0

67. Shushakova V, Fuller ER, Heidelbach F, Mainprice D, Siegesmund S (2013) Marble decay induced by thermal strains: simulations and experiments. Environ earth sci 69(4):1281-1297

68. Siegesmund S (2008) Neue Steine und alte Sorgen-Fassadenplatten aus Naturstein: Sicherheitsrisiken und Sanierungsstrategien. In: Venzmer H (Hrsg) 19. Hanseatische Sanierungstage Bauphysik und Bausanierung Heringsdorf 2008. Beuth Verlag, Berlin, S 17-27

69. Siegesmund S, Dürrast H (2014) Physical and mechanical properties of the rocks. In: Siegesmund S, Snethlage R (eds) Stone in architecture. Properties, durability, 5th edn. Springer

70. Siegesmund S, Grimm WD, Dürrast H, Ruedrich J (2010) Limestones in Germany used as building stones: an overview. Geol Soc Lond Special Publ 331(1):37-59

71. Siegesmund S, Rüdrich J, Koch A (2008) Marble bowing: comparative studies of three different public building façades. Environ Geol 56(3-4):473-494

72. Siegesmund S, Ullemeyer K, Weiss T, Tschegg EK (2000) Physical weathering of marbles caused by anisotropic thermal expansion. Int J Earth Sci 89(1):170-182

73. Silva Z (2017) The Portuguese Lioz, a monumental limestone. Geophysical Research Abstracts 19:EGU2017-E9019

74. Solancis (2021) Stone properties. http://www.solancis.com/stones. Accessed in 25th June 2021

75. Sousa L, Barabasch J, Stein K-J, Siegesmund S (2017) Characterization and quality assessment of granitic building stone deposits: a case study of two different Portuguese granites. Eng Geol 221:29-40. https://doi.org/10.1016/j.engge 0.2017 .01 .030

76. Sousa L, Menningen J, Sigesmund S (2020) Notes of a bowing behavior on limestone. In Siegesmund S, Middendorf B (Ed.), Monument Future: Decay and Conservation of Stone Proceedings of the 14th International Congress on the Deterioration and Conservation of Stone, Mitteldeuscher Verlag, pp. 145-150. ISBN: 987-3-96311-172-3

77. Sousa L, Siegesmund S, Wedekind W (2018) Salt weathering in granitoids: an overview on the controlling factors. Environ Earth Sci 77:502. https://doi.org/10.1007/s12665-018-7669-y

78. Sousa LMO, Oliveira AS, Alves IMC (2016) Influence of fracture system on the exploitation of building stones: the case of the Mondim de Basto granite (north Portugal). Environ Earth Sci 75:39. https://doi.org/10.1007/s1266 5-015-4824-6

79. Strohmeyer D (2003) Gefügeabhängigkeit technischer Gesteinseigenschaften. Dissertation, Universität Göttingen, 254 S

80. Stück H, Plagge R, Siegesmund S (2013) Numerical modeling of moisture transport in sandstone: the influence of pore space, fabric and clay content. Environ Earth Sci 69(4):1161-1187. https://doi.org/10.1007/s1266 5-013-2405-0 
81. Szemerey-Kiss B, Török Á (2017) Failure mechanisms of repair mortar stone interface assessed by pull-off strength tests. Bull Eng Geol Environ 76:159-167. https://doi.org/10.1007/s10064-016-0964-5

82. Taghipour M, Nikudel MR, Farhadian MB (2017) Engineering properties and durability of limestones used in Persepolis complex, Iran, against acid solutions. Bull Eng Geol Environ 75:967-978. https://doi.org/10.1007/s10064-015-0821-y

83. Tomašić I, Lukić D, Peček N, Kršinić A (2011) Dynamics of capillary water absorption in natural stone. Bull Eng Geol Environ 70:673-680. https://doi.org/10.1007/s10064-011-0355-x

84. Török A, Szemerey-Kiss B (2019) Freeze-thaw durability of repair mortars and porous limestone: compatibility issues. Progress in Earth Planetary Science 6:42. https://doi.org/10.1186/s40645-019-0282-1

85. Tugrul A, Zarif I (2000) Engineering aspects of limestone weathering in Istanbul, Turkey. Bull Eng Geol Env 58:191-206. https://doi.org/10.1007/s100640050075

86. Turgut P, Yesilnacar MI, Bulut H (2008) Physico-thermal and mechanical properties of Sanliurfa limestone, Turkey. Bull Eng Geol Environ 67:485-490. DOI 10.1007/s10064-008-0145-2

87. Uğur İ, Toklu H (2020) Effect of multi-cycle freeze-thaw tests on the physico-mechanical and thermal properties of some highly porous natural stones. Bull Eng Geol Environ 79:255-267. https://doi.org/10.1007/s10064-019-01540-z

88. Unterwurzacher M, Mirwald PW (2008) Initial stages of carbonate weathering: climate chamber studies under realistic pollution conditions. Environ Geol 56:507-519. https://doi.org/10.1007/s0025 4-008-1440-8

89. Urosevic M, Sebastián E, Cardell C (2013) An experimental study on the influence of surface finishing on the weathering of a building low-porous limestone in coastal environments. Eng Geol 154:131-141.

http://dx.doi.org/10.1016/j.enggeo.2012.12.013

90. Van Stappen JF, De Kock T, De Schutter G, Cnudde V (2019) Uniaxial compressive strength measurements of limestone plugs and cores: a size comparison and X-ray CT study. Bull Eng Geol Environ 78, 5301-5310 (2019). https://doi.org/10.1007/s10064-018-01448-0

91. Vázquez P, Alonso FJ, Carrizo L, Molina E, Cultrone G, Blanco M, Zamora I (2013) Evaluation of the petrophysical properties of sedimentary building stones in order to establish quality criteria. Constr Build Mater 41:868-878.

https://doi.org/10.1016/j.conbuildmat.2012.12.026

92. Vázquez P, Menéndez B, Denecker MF, Thomachot-Schneider C (2015) Comparison between petrophysical properties, durability and use of two limestones of the Paris region. In Přikryl R, Török A, Gómez-Heras M, Miskovsky K, Theodoridou M (eds) Sustainable Use of Traditional Geomaterials in Construction Practice. Geological Society, London, Special Publications,416, http://dx.doi.org/10.1144/SP416.15

93. Wang S, Sun Q, Wang N, Yang L (2020) Variation in the dielectric constant of limestone with temperature. Bull Eng Geol Environ 79:1349-1355. https://doi.org/10.1007/s10064-019-01647-3

94. Wedekind W, López-Doncel R, Dohrmann R, Kocher M, Siegesmund S (2013) Weathering of volcanic tuff rocks caused by moisture expansion. Environ Earth Sci 69:1203-1224. https://doi.org/10.1007/s1266 5-012-2158-1

95. Weiss T, Siegesmund S, Kirchner DT, Sippel J (2004) Insolation weathering and hygric dilatation: two competitive factors in stone degradation. Environ Geol 46(3-4):402-413

96. Yagiz S (2011) Correlation between slake durability and rock properties for some carbonate rocks. Bull Eng Geol Environ 70:377-383. https://doi.org/10.1007/s10064-010-0317-8

97. Yarahmadi R, Bagherpour R, Khademian A, Sousa LMO, Almasi SN, Esfahani MM (2019a) Determining the optimum cutting direction in granite quarries through experimental studies: a case study of a granite quarry. Bull Eng Geol Env 78:459-467. DOI 10.1007/s10064-017-1158-5

98. Yarahmadi R, Bagherpour R, Taherian S-G, Sousa LMO (2018) Discontinuity modelling and rock block geometry identification to optimize production in dimension stone quarries. Eng Geol 232:22-33.

https://doi.org/10.1016/j.enggeo.2017.11.006

99. Yarahmadi R, Bagherpour R, Taherian S-G, Sousa LMO (2019b) A new quality factor for the building stone industry: a case study of stone blocks, slabs, and tiles. Bull Eng Geol Env 78:533-542. DOI 10.1007/s10064-017-1040-5 
100. Yaşar E, Erdoğan Y, Güneyli H (2008) Determination of the thermal conductivity from physico-mechanical properties. Bull Eng Geol Environ 67:219-225. https://doi.org/10.1007/s10064-008-0126-5

101. Zammit T, Cassar J (2017) Investigating possible correlations between the porosimetry and insoluble residue content of Malta's Lower Globigerina Limestone. Bull Eng Geol Environ 76:59-70. https://doi.org/10.1007/s10064-015-0817-7

102. Zeisig A, Siegesmund S, Weiss T (2002) Thermal expansion and its control on the durability of marbles. Geol Soc Lond Spec Publ 205(1):65-80

103. Zenah J, Görög P, Török A (2020) Stability of Underground Excavation in Porous Limestone: Influence of Water Content. Acta Montanistica Slovaca 25(3):337-349. https://doi.org/10.46544/AMS.v25i3.7

\section{Figures}

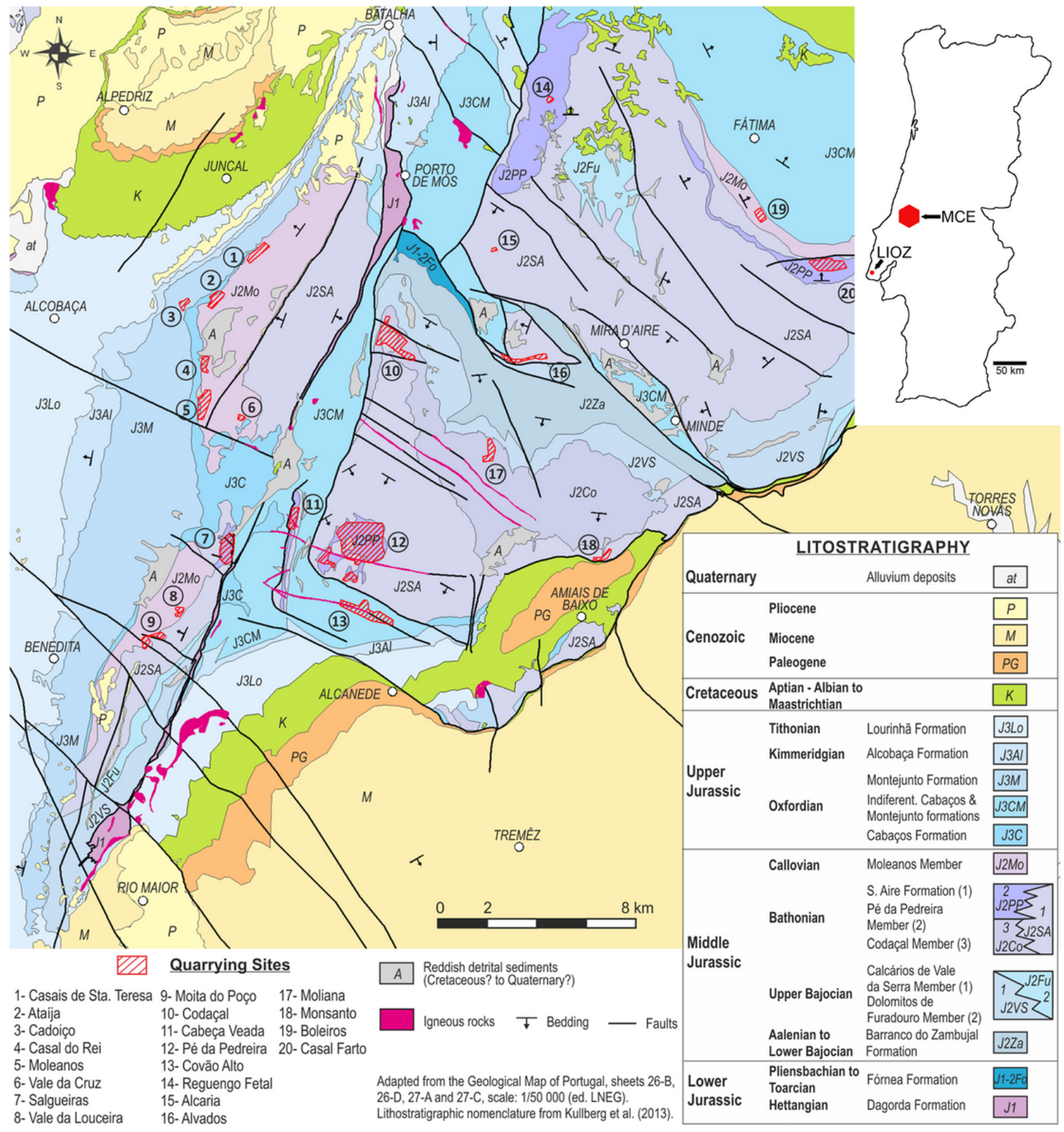

\section{Figure 1}


Location of the samples from the Maciço Calcário Estremenho (MCE) and LIOZ sample. Lithostratigraphic map of the MCE with the locations of quarrying sites (map modified from Carvalho and Lisboa 2018). MCE samples were collected in the following quarrying sites: $1,2,7,8,10,12$ and 18.

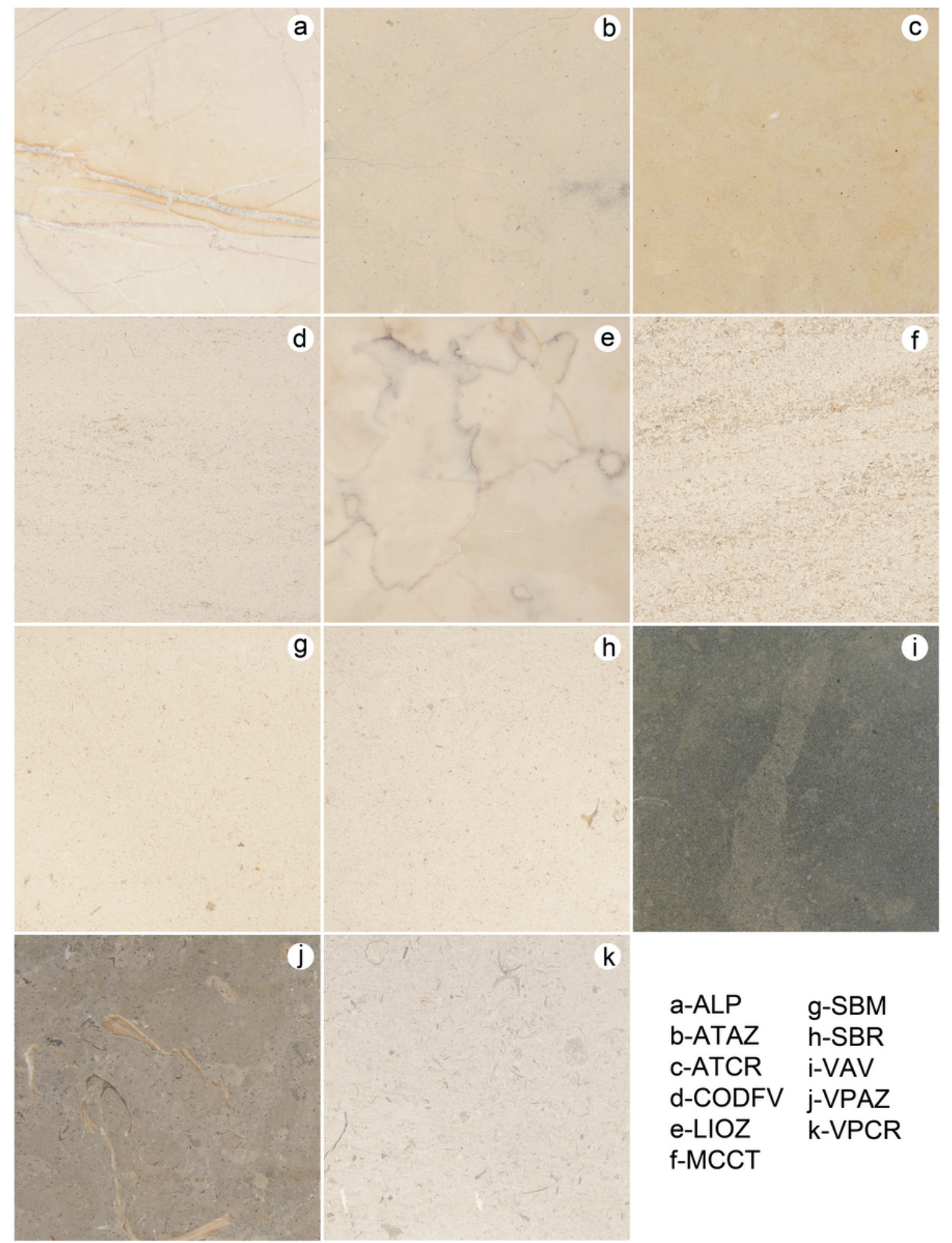

\section{Figure 2}

Macroscopic appearance of studied limestones (honed surfaces; size of the pictures: $10 \mathrm{~cm} \times 10 \mathrm{~cm}$ ) 


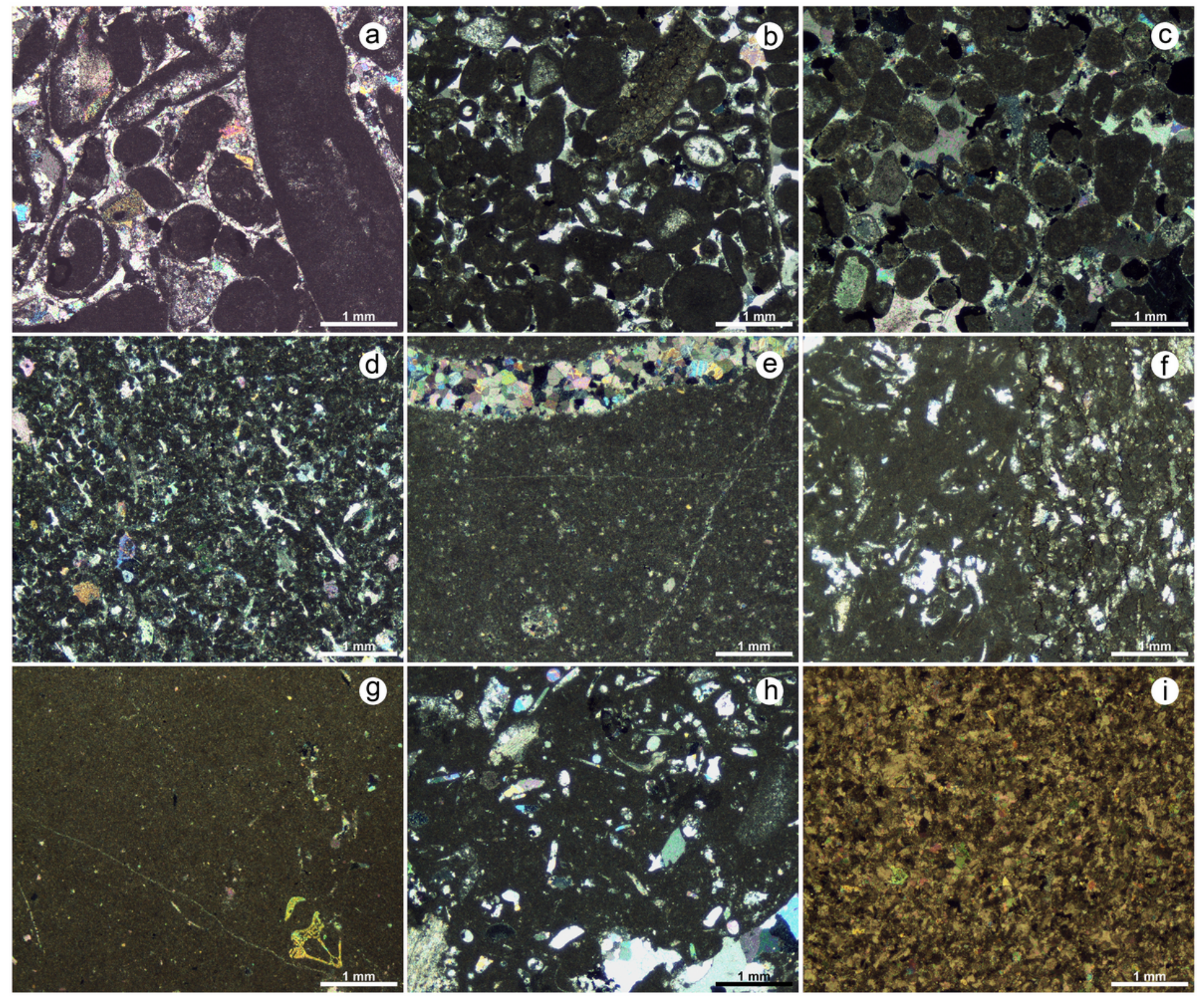

Figure 3

Microscope appearance of the studied limestones (a-MCCT; b-SBR; c-CODFV; d-ATAZ; e-ALP; f-VAV; g-VPAZ; h-VPCR; i-LIOZ) 

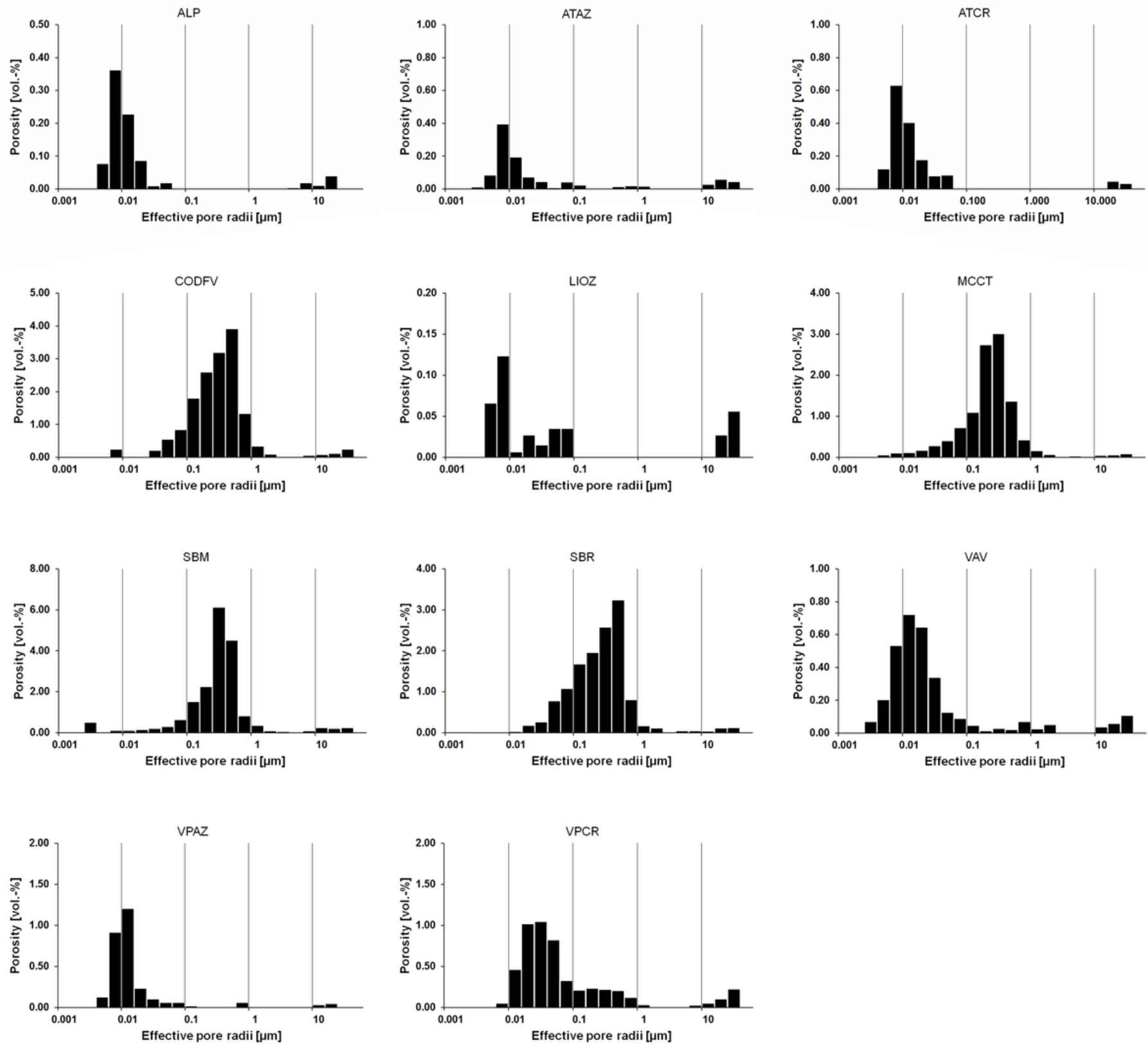

\section{Figure 4}

The unequal bimodal is the most frequent pore radii distribution of studied limestones 


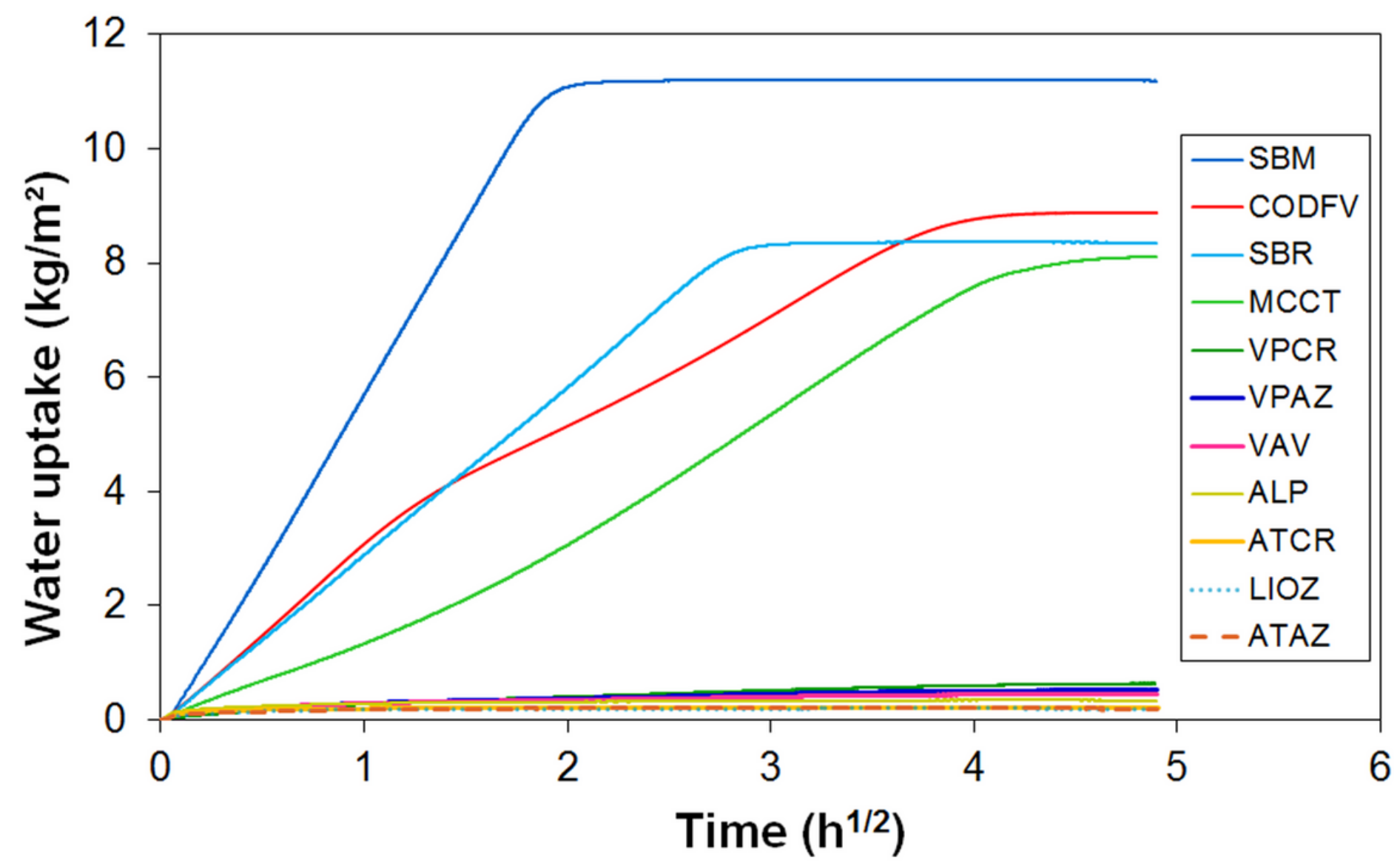

Figure 5

Evolution of the water uptake in the selected limestones. 


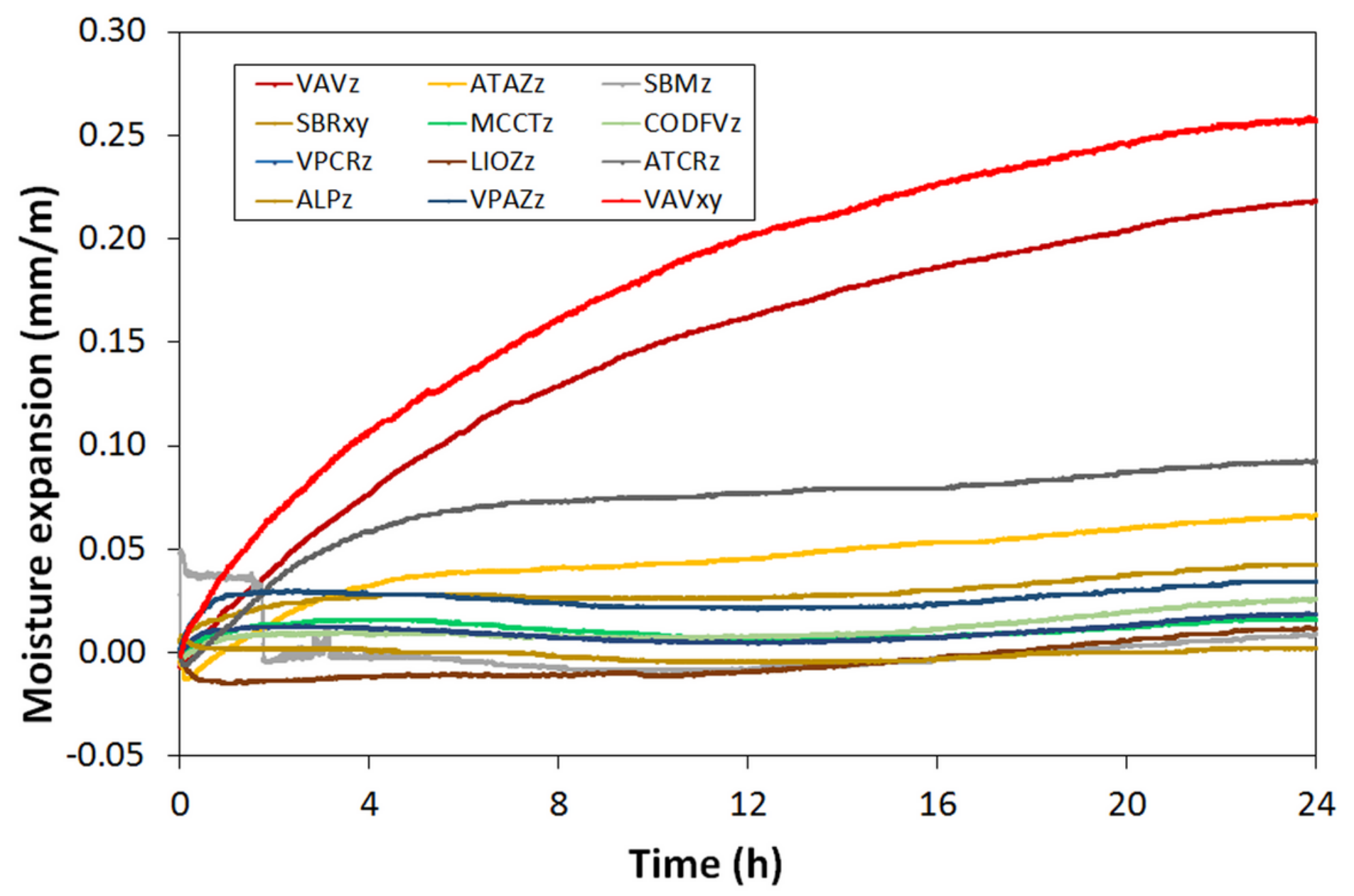

Figure 6

Hydric expansion of the studied limestones
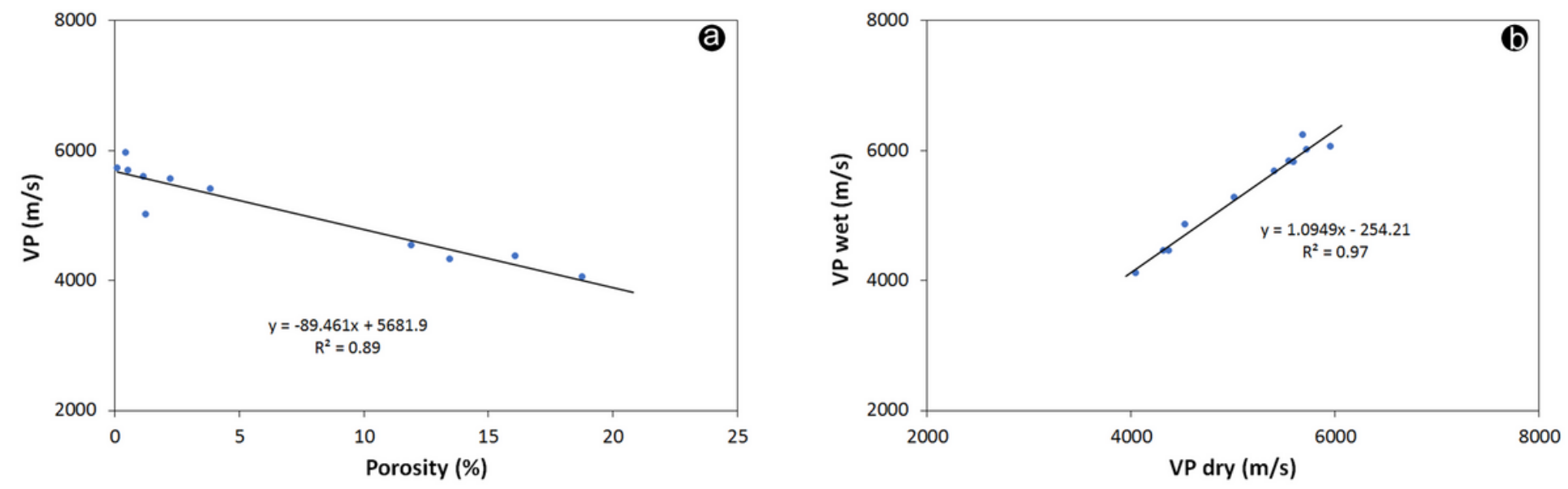

Figure 7

Relationship between VP and porosity (a) and VPwet and VPdry (b) 

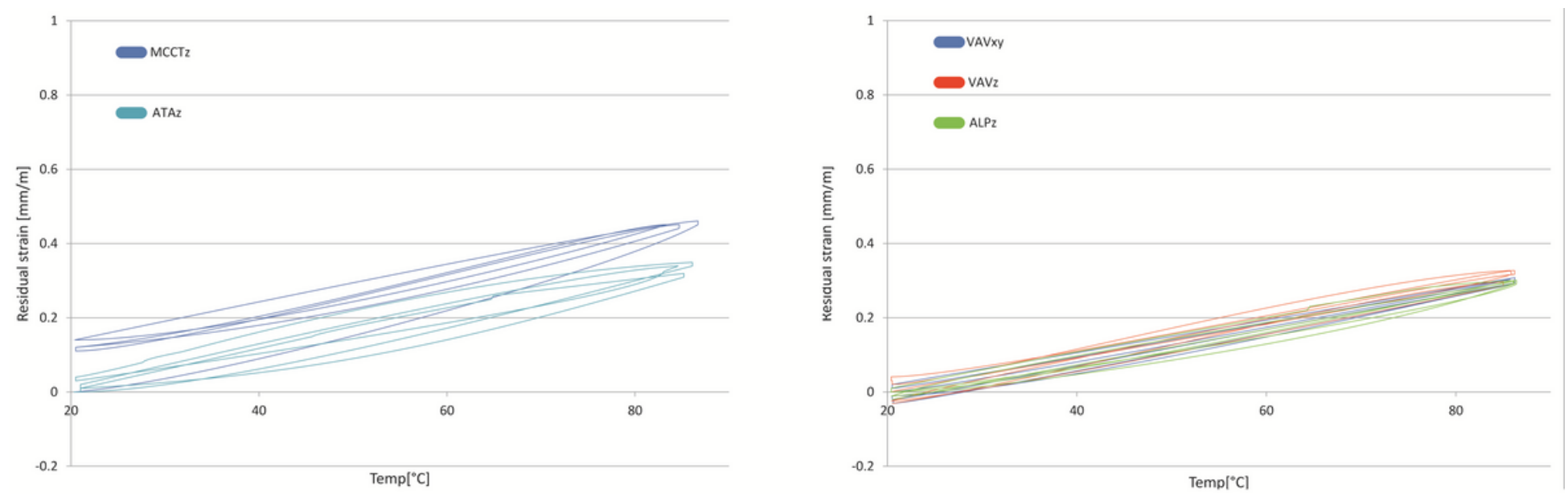

Figure 8

Examples of thermal dilatation $\varepsilon(\mathrm{mm} / \mathrm{m})$ shown for three dry cycles $\left(20-90-20{ }^{\circ} \mathrm{C}\right)$.
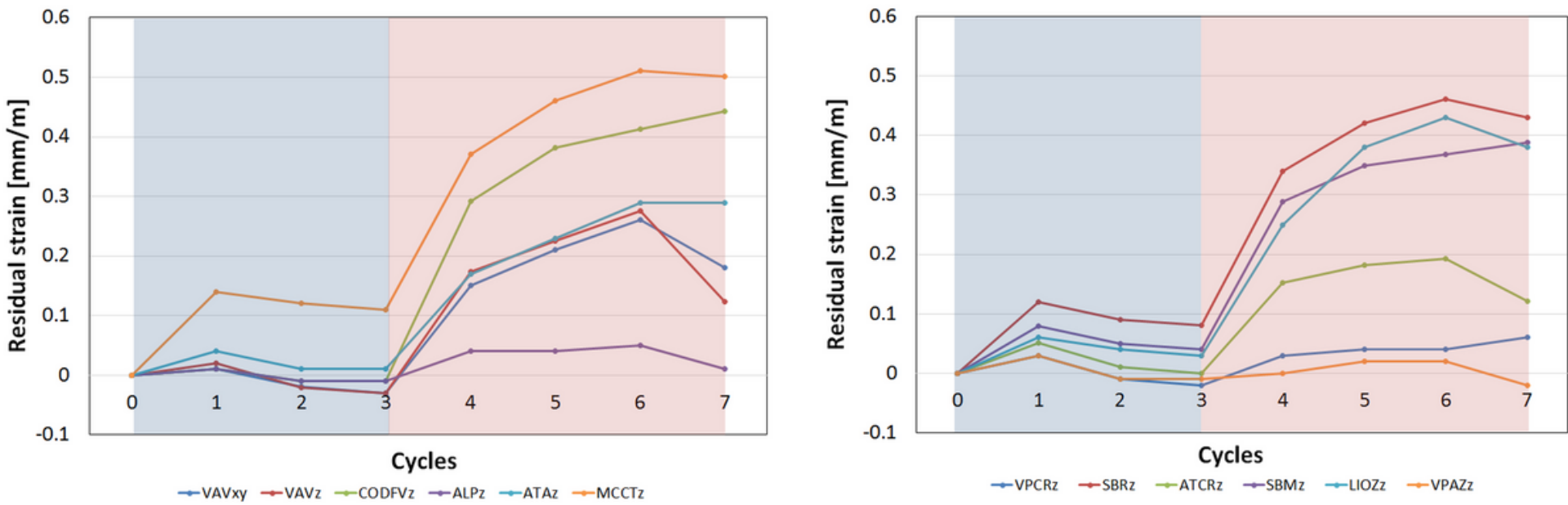

\section{Figure 9}

Progressive increase of residual strain for $20-90-20^{\circ} \mathrm{C}$ cycles of the selected samples, investigated as a function of the number of heating cycles under dry (3 cycles, blue background) and wet (4 cycles, red background) conditions.
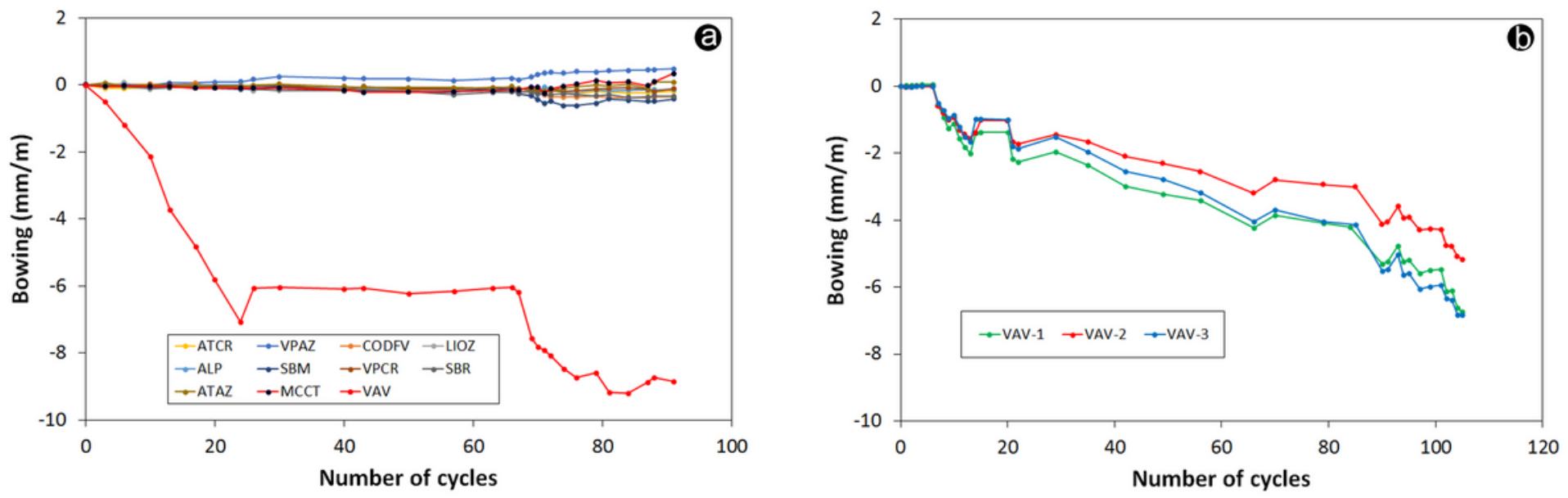

\section{Figure 10}

Results from bowing test. a) results from Sousa et al. (2020); b) new results. 


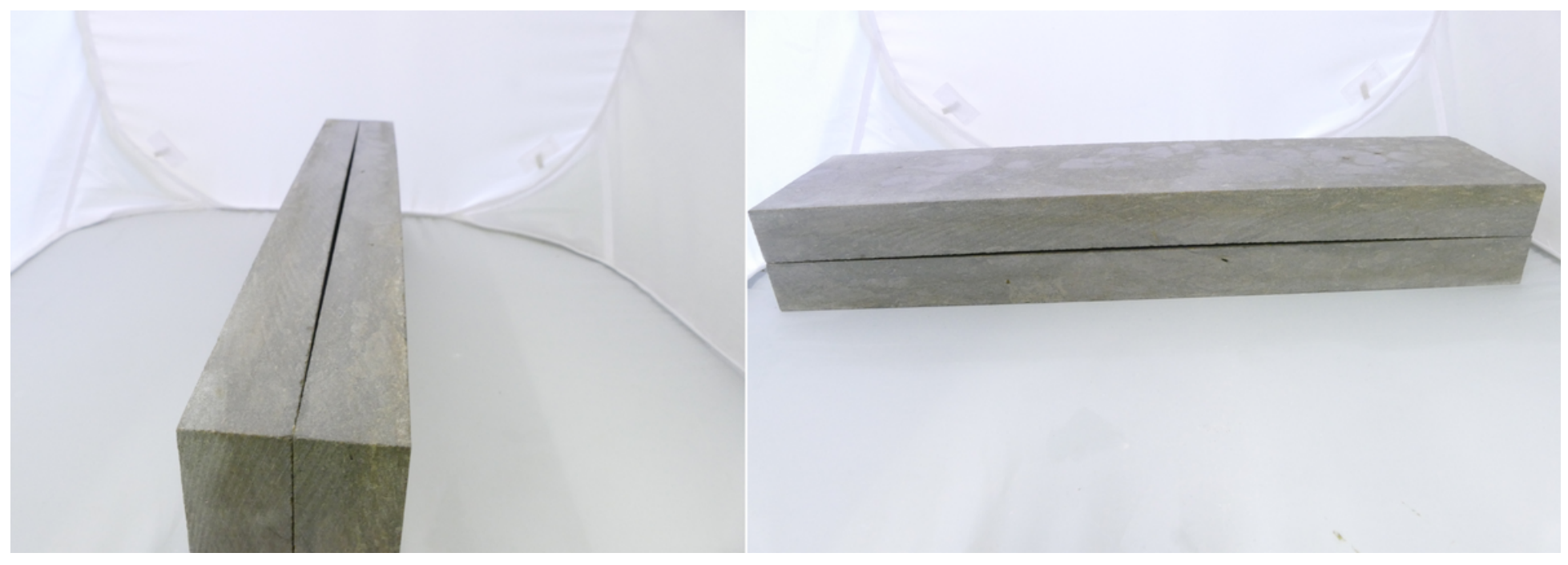

Figure 11

Visible bowing effect on VAV samples. The bending is visible when two specimens are put together.

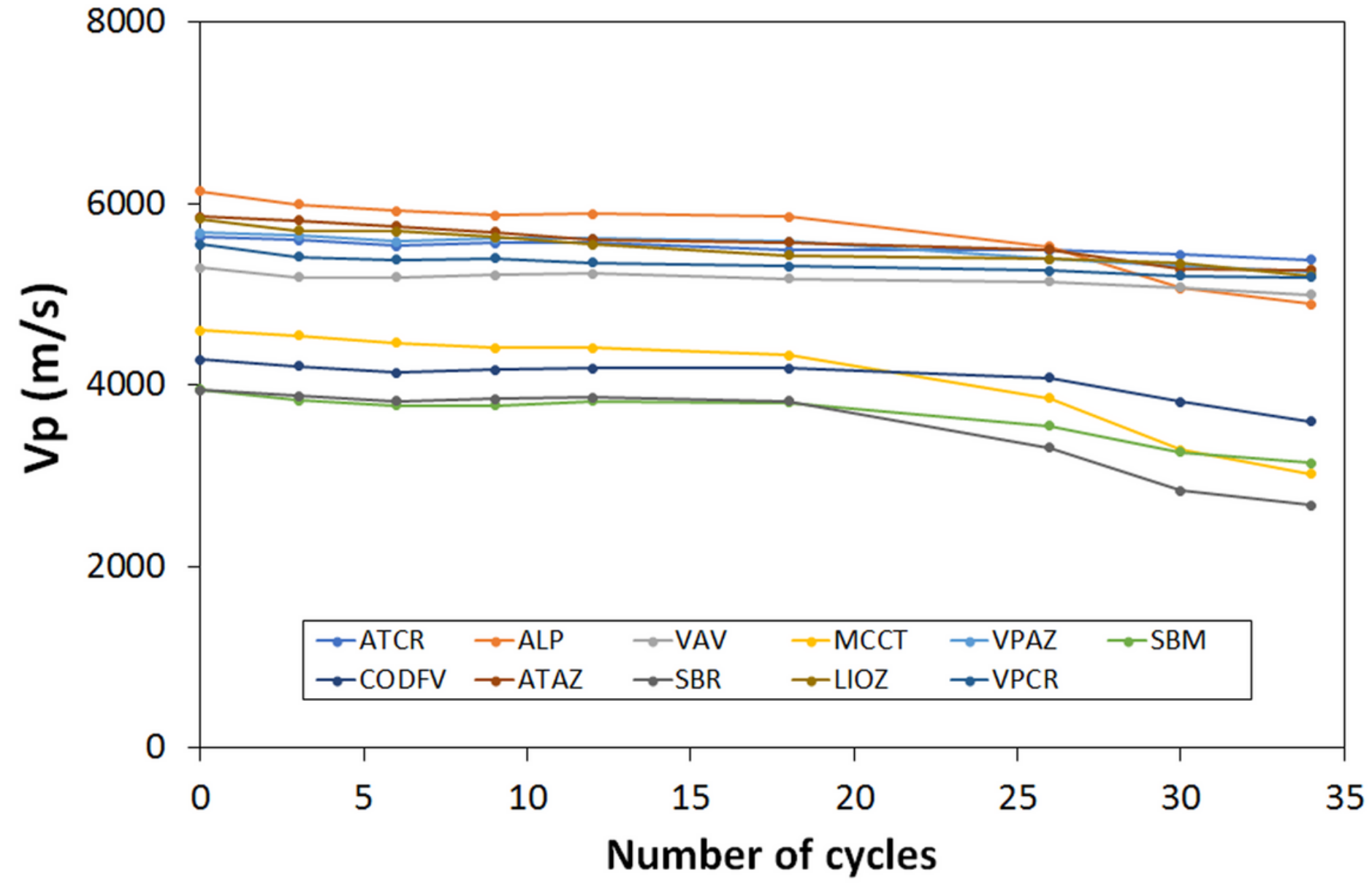

Figure 12

Evolution of compressional wave velocity during the thermal shock test 


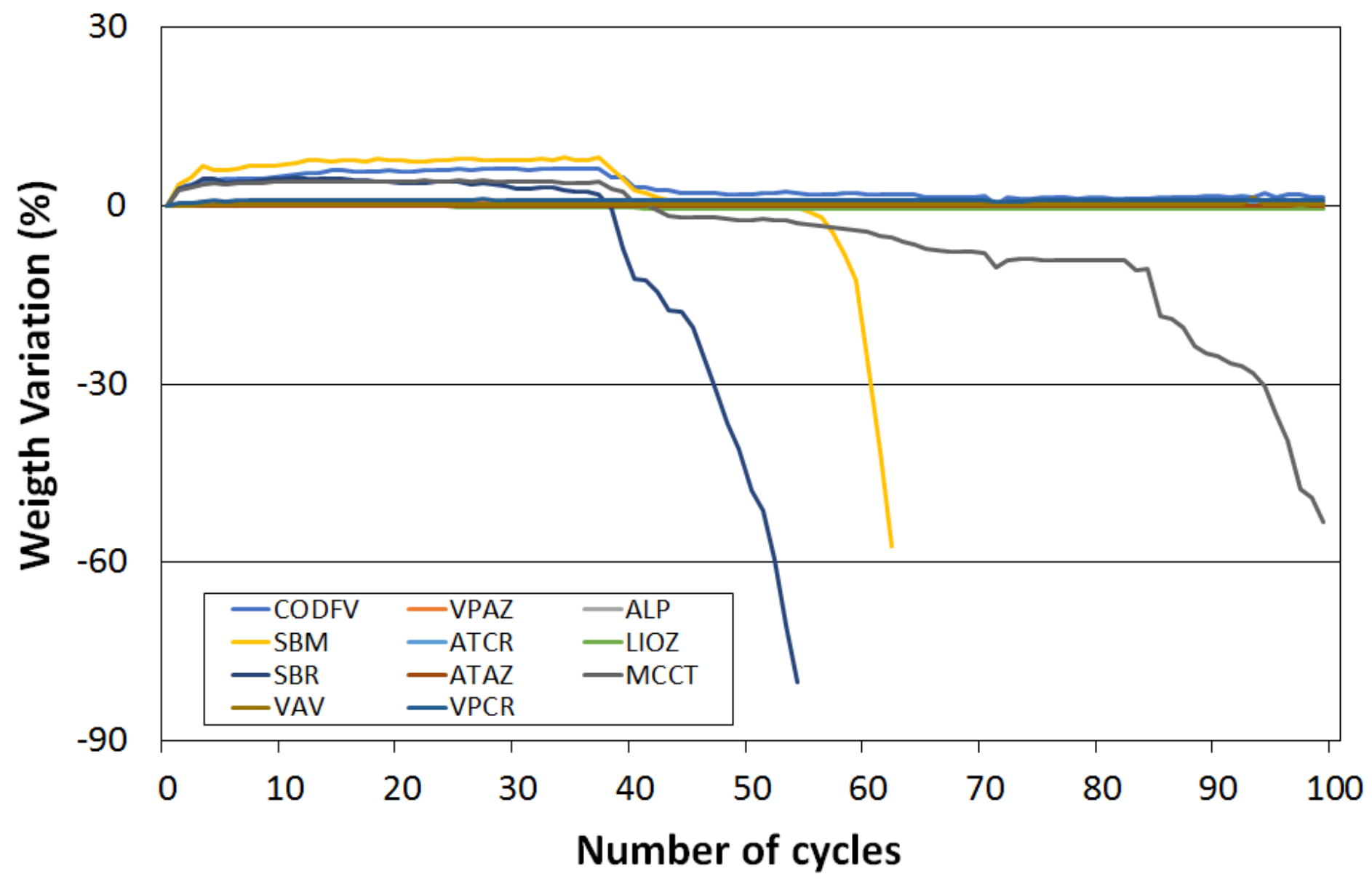

Figure 13

Weight variation during the salt crystallization test. 

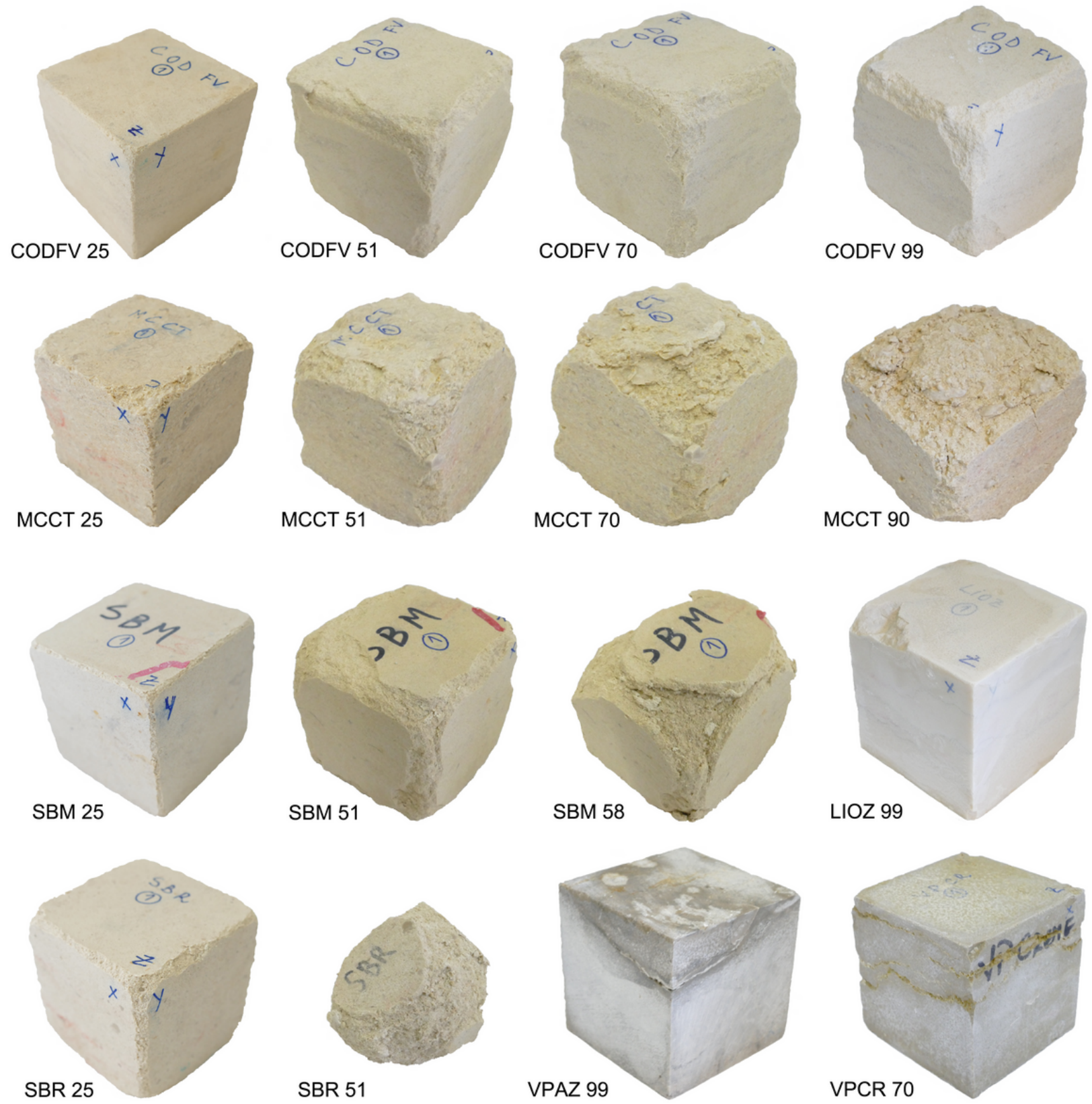

\section{Figure 14}

Evolution of selected samples during the salt test. 